NBER WORKING PAPER SERIES

\title{
UNWELCOME GUESTS? THE EFFECTS OF REFUGEES ON THE EDUCATIONAL OUTCOMES OF INCUMBENT STUDENTS
}

\author{
David N. Figlio \\ Umut Özek \\ Working Paper 23661 \\ http://www.nber.org/papers/w23661 \\ NATIONAL BUREAU OF ECONOMIC RESEARCH \\ 1050 Massachusetts Avenue \\ Cambridge, MA 02138 \\ August 2017
}

We are grateful to the Florida Department of Education and Florida Department of Health for providing the detailed, anonymous data necessary to conduct this research. This research was supported by the National Center for the Analysis of Longitudinal Data in Education Research (CALDER) funded through Grant R305A060018 from the Institute of Education Sciences, U.S. Department of Education. All opinions expressed in this paper are those of the authors and do not reflect the views of the Florida Departments of Education and Health or our funders. The views expressed herein are those of the authors and do not necessarily reflect the views of the National Bureau of Economic Research.

NBER working papers are circulated for discussion and comment purposes. They have not been peer-reviewed or been subject to the review by the NBER Board of Directors that accompanies official NBER publications.

(C) 2017 by David N. Figlio and Umut Özek. All rights reserved. Short sections of text, not to exceed two paragraphs, may be quoted without explicit permission provided that full credit, including $\odot$ notice, is given to the source. 
Unwelcome Guests? The Effects of Refugees on the Educational Outcomes of Incumbent Students

David N. Figlio and Umut Özek

NBER Working Paper No. 23661

August 2017

JEL No. I20,J10

\title{
ABSTRACT
}

The world is experiencing the second largest refugee crisis in a century, and one of the major points of contention involves the possible adverse effects of incoming refugees on host communities. We examine the effects of a large refugee influx into Florida public schools following the Haitian earthquake of 2010 using unique matched birth and schooling records. We find precise zero estimated effects of refugees on the educational outcomes of incumbent students in the year of the earthquake or in the two years that follow, regardless of the socioeconomic status, grade level, ethnicity, or birthplace of incumbent students.

\author{
David N. Figlio \\ Institute for Policy Research \\ Northwestern University \\ 2040 Sheridan Road \\ Evanston, IL 60208 \\ and NBER \\ figlio@northwestern.edu \\ Umut Özek \\ American Institutes for Research/CALDER \\ 1000 Thomas Jefferson St. NW \\ Washington, DC 20007 \\ uozek@air.org
}




\section{UNWELCOME GUESTS? \\ THE EFFECTS OF REFUGEES ON THE EDUCATIONAL OUTCOMES OF INCUMBENT STUDENTS}

\section{Introduction}

The world is experiencing a refugee crisis of a magnitude not seen since the end of World War II. According to the figures released by the United Nations High Commissioner for Refugees (UNCHR), as of the end of 2015, there were 65.3 million refugees and internally displaced people around the globe - the largest number in history. More than a million Middle Eastern refugees crossed into Europe in 2015, triggering a series of major political and humanitarian crises as countries scramble to cope with the influx. The ripple effects of this new wave of refugees are also felt across the Atlantic, with the number of asylum seekers from Middle Eastern countries reaching record highs in the United States and Canada and sparking spirited political debates. The main point of contention in debates on refugees is the possible adverse effects of refugees on host communities; however, these debates mostly take place in what is close to an empirical vacuum.

In this study, we present the first evidence, to the best of our knowledge, on the effects of a large influx of refugees on the educational outcomes of incumbent students. We focus specifically on one of the largest recent inflows of refugees into the United States - those who entered immediately following the devastating earthquake on January 12, 2010 that killed more than 200,000 people and affected a third of the population in Haiti; approximately 60,000 earthquake survivors moved to the United States immediately following the earthquake. We make use of rich, longitudinal education microdata from the Florida - host to two-thirds of the Haitian refugees -- to study this question. These data are exceptionally detailed, allowing us to investigate the effects of Haitian refugees on a variety of incumbent students, including nonrefugee Haitian immigrants, U.S.-born students of Haitian ancestry, other non-Haitian immigrant 
students, and so on. Over 4,000 refugee students entered Florida public schools by the end of the 2009-10 school year, and the overwhelming majority of these students enrolled in four school districts, generating a significant influx of refugee students in certain schools.

A number of studies have examined the effects of immigrants on the labor market outcomes of host communities ${ }^{1}$, and there have been several recent analyses of the effects of immigrants per se on the educational outcomes of incumbent students ${ }^{2}$, though their conclusions have been mixed. ${ }^{3}$ But the effects of refugees might differ from the effects of immigrants on native communities due to the fundamental differences between these two groups in the manner in which they left their home countries. Immigrants typically make conscious choices to leave their countries of origin seeking "a better life" elsewhere. On the other hand, the term "refugee” refers to people who have to flee their countries due to an imminent threat to their lives such as armed conflicts, persecution, and/or natural disasters, and hence are more likely to be

\footnotetext{
${ }^{1}$ Most studies investigating the effects of immigrants on the labor market outcomes of natives find little or no effect (e.g., Dustmann et al. (2008), Borjas (2013)), yet some find significant negative effects of immigrant influxes on the wages and employment rates of low-skilled natives (e.g., Card, 2001). For a brief overview of the existing literature in this context, see Akgündüz et al. (2015).

${ }^{2}$ Using the large immigrant influx into Israel in the 1990s, Gould et al. (2009) exploit the cross-cohort, withinschool variation in immigrant concentration to study the effects of immigrants, and find a large adverse effect on the high school dropout rates and high school matriculation test passing rates among native Israeli students. Similarly, Jensen and Würtz-Rasmussen (2011) find negative effects of immigrant concentration on both native and immigrant secondary school students in Denmark. In the United States, Betts and Fairlie (2003) and Cascio and Lewis (2012) find that inflows of immigrants increase the native flight across school districts and from public schools into private schools, especially among native-born white students in secondary grades. Further, using pooled 1980 and 1990 Census data, Betts (1998) finds a significant negative effect of immigrants on the likelihood of high school graduation among black and Hispanic students in the United States. In contrast, there are several studies that find no significant effect, or even a positive effect, of immigrants on the educational outcomes of native students. For instance, Hunt (2012) finds that an increase in the immigrant share in the population increases the likelihood of high school graduation among native-born black students in the United States. Similarly, Brunello and Rocco (2013) and Geay et al. (2012) find small or no negative spillover effects of immigrants on natives, and Ohinata and Van Ours (2013) and Schneeweis (2015) find large negative effects of immigrant concentration on the educational outcomes of immigrant students, yet no significant effect on natives.

${ }^{3}$ A closely related line of research examines the effect of racial/ethnic diversity in schools on student outcomes in the United States. For example, Hanushek et al. (2009) and Hoxby (2000) investigate the effects of school racial composition on the educational outcomes of black and white students in Texas, and find that a higher percentage of black peers reduces the achievement of black students, but the effect on whites is generally insignificant and smaller. Angrist and Lang (2004) reach similar conclusions examining the school desegregation program in Boston.
} 
representative of, or even less advantaged and more marginalized than, the general population in their countries of origin (Cortes, 2004). Refugees generally are more impoverished with lower earnings than economic migrants, and have lower levels of education and language skills when they arrive (Connor, 2010; Potocky-Tripodi, 2004). ${ }^{4}$ And while refugees ultimately - after a period of six to ten years -- have higher labor force participation and employment rates, and have similar welfare participation rates, relative to U.S.-born residents, they often enter the U.S. with low human capital and language skills and have initially poor labor market outcomes and high rates of welfare usage (Evans and Fitzgerald, 2017). Therefore, it is plausible to expect that refugees might have a very different (and likely more adverse) effect on incumbent students as school districts and schools shift resources away from native students to accommodate the needs of refugees.

The biggest challenge in revealing the causal effect of refugees on incumbent communities is that refugee students are not randomly assigned to schools and communities. In fact, prior research has shown that refugees, and recent immigrants in general, are more likely to settle in neighborhoods with larger shares of immigrants from their country of origin (see, e.g., Card, 2001). To deal with this selection issue, we make use of the within-school, across-grade variation in the volume of entering refugees to explore the effects on the educational outcomes of existing students including test scores, disciplinary incidents, and student mobility across schools. We also use the birth dates of refugee students as an instrument for their grade placement to deal with the possible strategic placement of refugee students across grades within schools. We find precisely estimated zero effects (with occasional positive estimates as well) of refugees on the educational outcomes of incumbent students in the year of the earthquake or in

\footnotetext{
${ }^{4}$ Beaman (2012) shows that refugees perform better in the labor market when they reside in communities with larger numbers of other refugees.
} 
the two years that follow, regardless of the socioeconomic status, grade level, or the birthplace of incumbent students.

\section{The Haitian Earthquake of 2010}

A powerful 7.0-magnitude earthquake struck Haiti’s capital Port-au-Prince on January 10, 2010, killing more than 200,000 people and affecting more than three million people (almost a third of the country's entire population), more than a million of whom were left homeless. After the earthquake, the United States granted 60,000 Haitian refugees temporary protected status which provided relief from deportation and work authorization until January, 2016. Of those 60,000 refugees, 38,000 settled in Florida. ${ }^{5}$

This influx of Haitian refugees also led to a sizeable refugee shock in Florida public schools. In the first two months after the earthquake, more than 2,000 Haitian refugees entered Florida public schools, and roughly 4,000 entered by the end of the spring semester in $2010 .^{6}$ Figure 1 portrays the distribution of Haitian immigrants entering Florida public schools during the spring semesters between 2003-04 and 2011-12 school years, suggesting that the number of Haitian immigrants entering the public school system in Florida more than quadrupled in Spring 2010, and reverted to its pre-2010 levels in the following year. Table 1 presents the number of schools by refugee concentration, broken down by grade level, indicating that approximately 40 percent of the schools in Florida did not receive any Haitian refugees in Spring 2010 whereas the share of Haitian refugees exceeded one percent of the student body in 100 schools in Florida.

Figure 2 maps these 100 schools, which we call "top refugee-receiving schools" in the remainder

\footnotetext{
${ }^{5}$ http://articles.orlandosentinel.com/2013-01-11/business/os-haiti-earthquake-central-florida-20130111_1_haitianrefugees-haitian-nationals-immigration-officials, accessed on 6/7/2017.

${ }^{6}$ Authors' calculations from student-level enrollment data.
} 
of the paper, and shows that these schools are mainly concentrated in four school districts (Broward, Miami-Dade, Orange, and Palm Beach).

\section{Data and Empirical Strategy}

In this study, we use student-level administrative data from Florida that provide detailed information about all students enrolled in a public school between 2002-03 and 2011-12. School records contain reading and math scores on the Florida Comprehensive Assessment Test (FCAT) of all students between grades three and ten, along with a wealth of student characteristics including student demographics (e.g., race/ethnicity, gender), free-or-reduced-priced lunch (FRPL) eligibility, measures of English proficiency (limited English proficiency indicator and language spoken at home), detailed information about disciplinary incidents (including the precise date of the incident), and special education status. More importantly for the purposes of this study, we observe the country of birth and the entry dates of all students to the schools they attended in a given school year, which allow us to identify Haitian refugees who entered the Florida public school system after the earthquake. We also observe home language, which allows us to identify U.S.-born students of recent Haitian descent.

For the purposes of this research agenda, the Florida Departments of Education and Health linked these student-level administrative data with student birth records for every child born in Florida between 1992 and 2002. Birth records offer background information not typically seen in school records such as parental education, providing additional measures of student socioeconomic status. Because the birth-school match is based on full name, exact date of birth, 
and social security numbers, the birth and school records are virtually perfectly matched (Figlio et al., 2014). ${ }^{7}$

Table 2 compares the characteristics of Haitian refugees (first column) with immigrants who entered Florida public schools in Spring 2010 (second column) and Haitian immigrants who entered the school system during spring semesters before the earthquake (third column). Compared with Haitian immigrants in other years, Haitian refugees are significantly more likely to be economically disadvantaged, and while they are just as likely to be non-native English speakers, they are much more likely to be identified as limited English proficient upon entry into the school system. In particular, almost 90 percent of Haitian refugees were eligible for free or reduced price lunch (compared to 63 percent for other immigrants in Spring 2010 and 72 percent for Haitian immigrants in other spring semesters), and 91 percent were limited English proficient (compared to 74 percent for other immigrants in Spring 2010 and 52 percent for Haitian immigrants in other spring semesters). Haitian refugees also are more economically disadvantaged and have lower facility in English than are immigrants from other countries arriving in Spring 2010. In sum, Haitian refugees are considerably more needy than other immigrants - Haitian or otherwise.

The previous literature has shown that recent immigrants are more likely to settle in neighborhoods with larger shares of immigrants, typically from their countries of origin. ${ }^{8}$ This is also the case for Haitian refugees, as demonstrated in Table 3. Existing students in refugeereceiving schools are significantly more likely to speak Haitian Creole, more likely to have been

\footnotetext{
${ }^{7}$ As Figlio et al. (2014) demonstrate, the match rate is essentially identical to that which would have been predicted based on the American Community Survey data.

${ }^{8}$ Immigrants also tend to be concentrated in part because native students frequently leave schools when facing a major immigrant influx (Schindler-Rangvid (2010), Gerdes (2010), Betts and Fairlie (2003), and Cascio and Lewis (2012)).
} 
born abroad, and in Haiti in particular, have significantly lower prior achievement levels, are more likely to be FRPL eligible, less likely to be white, and more likely to be limited English proficient. Florida-born students in these schools are also less likely to have educated mothers. These stark differences in baseline characteristics imply that the observed differences in student outcomes are likely to be contaminated by differences in unobserved student traits between schools that received refugees versus others.

To deal with this selection issue, following Gould et al. (2009), we rely on within-school, across-grade variation in refugee concentration to study the effects of the refugee influx on incumbent students. In particular, we estimate the following equation:

$$
Y_{i t s g}=\alpha+\beta R_{s g}+\delta_{s}+\theta_{g}+\varepsilon_{i t s g}
$$

where $Y_{i t s g}$ is the year $t$ educational outcome of student $i$ who attended school $s$ and grade $g$ in Spring 2010, $R_{s g}$ is the percentage of Haitian refugees in grade $g$ and school $s$ in Spring 2010, $\delta_{s}$ and $\theta_{g}$ are the fixed effects of the school and the grade that student $i$ attended in Spring 2010 respectively. ${ }^{9}$ As primary outcomes of interest we use test scores in reading and math standardized to zero mean and unit variance at the grade-year level, an indicator for whether the student was involved in a serious disciplinary incident resulting in a suspension, and student mobility (i.e., whether the student moved to another school or left the Florida public school system altogether by Fall 2010 or Fall 2011). We also create a performance index using the estimated coefficients of test scores and disciplinary incidents in $8^{\text {th }}$ grade in a regression where we predict on-time high school graduation (Appendix Table A1 presents the means and standard

\footnotetext{
${ }^{9}$ In some specifications, we also include a vector of student characteristics $\left(X_{i t}\right)$ including prior test scores, disciplinary incidents, and student demographics to check the robustness of our findings. We adjust all standard errors for clustering at the school level.
} 
deviations of our outcome variables in Spring 2010 along with the two school years that follow for refugee-receiving and top-refugee receiving schools in our sample). ${ }^{10}$

In our analysis, we focus on the within-cohort refugee concentration in Spring 2010 because it is less likely that incumbent students were able to respond to the unexpected refugee influx (e.g., by changing schools) immediately after the earthquake. Therefore, it is more plausible to expect that the cross-grade variation in refugee concentration in Spring 2010 is uncorrelated with the observed and unobserved characteristics of existing students within schools, which is the critical assumption behind our identification strategy here. Table 4 checks the validity of this assumption by replacing student outcomes with student and teacher characteristics (experience and level of education, averaged at the school-by-grade level) in model (1) and estimating the equation with and without school fixed effects, for all schools and top refugee-receiving schools separately. The findings reported in the first and third columns reveal strong correlations between baseline characteristics and refugee concentration across schools, yet these correlations vanish in almost all cases when school fixed effects are introduced - at least for the top refugee-receiving schools that are the focus of our analysis.

While these findings provide suggestive evidence that our identification assumption is valid, it is still plausible that school administrators strategically place refugees in grades based on unobservable factors. For this, we use the age distribution of entering refugees in each school as an instrument for the refugee concentration. In particular, using 2SLS, we also estimate:

$$
\begin{gathered}
R_{s g}=\phi+\gamma A_{s g}+\delta_{s}+\theta_{g}+v_{s g} \\
Y_{i t}=\rho+\mu \hat{R}_{s g}+\delta_{s}+\theta_{g}+\vartheta_{i t}
\end{gathered}
$$

\footnotetext{
${ }^{10}$ In particular, using 5 cohorts of first-time $9^{\text {th }}$ graders between 2003 and 2007, we regress an indicator of whether the student received a standard high school diploma in four years after entering the $9^{\text {th }}$ grade for the first time on $8^{\text {th }}$ grade reading and math scores, and an indicator of whether the student was involved in a disciplinary incident in the $8^{\text {th }}$ grade. Using the estimated coefficients ( 0.07 for reading, 0.10 for math, and -0.23 for disciplinary incident), we construct a performance index for all students in our sample for whom test scores are available.
} 
where $A_{s g}$ is the number of refugees who entered school $s$ and were age-appropriate for grade $g$, divided by the number of existing students enrolled in the same school-grade. Appendix Table 2 presents the correlations between $A_{s g}$ and student and teacher characteristics (once again averaged at the school-by-grade level) for all schools and top-receiving schools, providing further evidence supporting the exogeneity of the instrument. Especially when we restrict our attention to the top refugee-receiving schools, which together account for 40 percent of the total Haitian refugee population, there is little evidence of a within-school relationship between covariates and the age distribution of refugees.

\section{Results}

We next turn to investigating the relationship between refugee concentration and incumbent student outcomes following the earthquake. We consider three years of postearthquake data: Spring 2010, when refugees were still entering the schools, ${ }^{11}$ and in the 2010-11 and 2011-12 academic years, after the refugee absorption was essentially complete. Table 5 presents the effects of refugee concentration on incumbent student test scores in reading and math, disciplinary incidents, and our index of performance, estimated using OLS for all refugeereceiving schools and top refugee-receiving schools in Spring 2010 (first panel), 2010-11 school year (second panel), and 2011-12 school year (third panel). Appendix Table 3 presents the same effects estimated using IV models. In models without school fixed effects, it appears as if more refugees are associated with worse student outcomes (negative relationships with test scores and the performance index and positive relationships with disciplinary incidents), but this is entirely driven by differential selection into the schools that Haitian refugees attend. Indeed, as soon as

\footnotetext{
${ }^{11}$ The FCAT was administered in Spring 2010 between March 9-19, only two months following the earthquake. At that point, only around half of the Haitian refugees who would ultimate attend Florida public schools by the end of that academic year had even entered the schools.
} 
we control for school fixed effects and consider only the naturally-occurring variation in refugee concentration across grades within the same school, the negative relationships disappear and the estimates are invariably non-negative ${ }^{12}$, and even positive with respect to reading test scores in the top refugee-receiving schools where most of the refugees attend. In the top refugee-receiving schools, our preferred estimates (those with both school fixed effects and student covariates included) in Spring 2010 indicate that each percentage point increase in refugee concentration is associated with 0.6 to 0.7 percent of a standard deviation increase in reading test scores and 0.3 to 0.4 percent of a standard deviation in math test scores, and 0.2 to 0.6 percentage points fewer disciplinary incidents ${ }^{13}$. The estimates are of approximately the same magnitudes in the 2010-11 and 2011-12 school years as well. These are very modest estimates, but none suggest a deleterious effect of refugees on incumbent students in the initial year of the earthquake. Indeed, the standard errors in our preferred models are sufficiently small that we could statistically detect effects of smaller than one percent of a standard deviation changes in test scores (1.5 percent of a standard deviation in the IV models) for every percentage point increase in the refugee concentration. ${ }^{14}$ Given that only four Florida schools had a refugee concentration of over five percent of their school population, our take-away is that we have estimated precise zero (except in the case in which we estimate precise but very modest positive) effects of refugees on the incumbent population's test scores and disciplinary problems.

\footnotetext{
${ }^{12}$ A negative coefficient when the dependent variable is the presence of a disciplinary incident is evidence of a positive outcome.

${ }^{13}$ We tend to prefer the test score outcomes to those regarding disciplinary incidents, because classroom disciplinary policies may be affected by student body composition but the tests, which are state-administered and centrallygraded, are not influenced by student body composition.

${ }^{14} \mathrm{We}$ also estimate models where we cluster standard deviations at the district level. Standard errors increase modestly, but they are still sufficiently small to detect statistically significant effects as small as $1.5-2$ percent of a standard deviation in test scores for every percentage point increase in the refugee concentration.
} 
Appendix Table 4 examines the extent to which the second and third year effects observed in Table 5 are driven by differential student attrition from the sample. In this exercise, we re-estimate (using our preferred specification that includes school fixed effects and student covariates) the effects of refugee concentration on student test scores, disciplinary incidents, and the performance index using all students (columns labeled as (I)), using students who remained in the sample in 2010-11 school year (columns labeled as (II)), and using students who remained in the sample in 2011-12. The first year effects remain unchanged, providing evidence that differential attrition is not a major issue for our second and third year estimates. ${ }^{15}$

Table 6 examines the effects of refugee concentration on the likelihood of incumbent student mobility in the following two years, estimated using OLS (IV results are presented in Appendix Table 5). While models that do not include school fixed effects provide some evidence of increased incumbent student mobility across Florida public schools, most of these relationships vanish when we account for differences in student mobility across schools. In our preferred specification that includes school fixed effects and student covariates using top refugee-receiving schools, OLS estimates suggest that one percentage point increase in refugee concentration increases the likelihood of student movement to another public school by Fall 2010 by 0.1 percentage points while decreasing the likelihood of exiting the school system by the same amount. Similarly, one percentage point increase in refugee concentration increases withinschool system student movement by 0.01 percentage points, and decreases the likelihood of exiting the school system by 0.5 percentage points by Fall 2011. Of these estimates, only the

\footnotetext{
${ }^{15}$ We also conduct a bounding exercise (results are available upon request) to assess the extent of differential student attrition. In this exercise, we assign each student who leaves the Florida public school system by Fall 2010 or Fall 2011 a test score that corresponds to the $5^{\text {th }}$ percentile (lower bound) or the $95^{\text {th }}$ percentile (upper bound) of the test score distribution in reading and math, or a disciplinary incident value of zero (lower bound) or one (upper bound), and re-estimate our preferred specification that includes school fixed effects and student covariates. In summary, the overall evidence indicates that refugees had little negative - and potentially even positive - effects on incumbent students' outcomes in the two years following the earthquake.
} 
effect on Florida public school system exit by Fall 2011 is statistically significant at conventional levels, suggesting that more Haitian refugees might have decreased the likelihood that students would leave affected schools, and again, the magnitudes of this difference are quite small.

One possible mechanism behind these precisely estimated zero effects of refugees on incumbent students is that refugees are placed in different classrooms within grades. To see whether this is the case, columns labeled as (I) in Table 7 presents the differences in incumbent student characteristics between refugee-receiving classrooms and others in refugee-receiving schools and top refugee-receiving schools, controlling for school-by-grade fixed effects. The results reveal significant differences between refugee-receiving classrooms and others although refugee students were by no means completely isolated from incumbent students. For instance, refugees are significantly more likely to be placed in classrooms with higher shares of Haitianborn students (38 percent versus 12 percent in top refugee-receiving schools), Haitian-Creole speakers (49 versus 30 percent), and higher shares of limited English proficient students (54 versus 12 percent). Given that 90 percent of all Haitian refugees were identified as limited English proficient (LEP) upon entry into the Florida public school system, these discrepancies might be explained by some schools instructing LEP students in separate classrooms than fluent English speakers (i.e., sheltered classrooms). ${ }^{16}$ Indeed, when we control for the LEP status of incumbent students (in columns labeled as (II)), differences in classroom characteristics diminish dramatically. For instance, incumbent students in refugee-receiving classrooms within top

\footnotetext{
${ }^{16}$ The Florida Department of Education uses several instructional models for English learners including (1) sheltered models where English learners are placed in separate classrooms only for English courses; (2) sheltered models where English learners are placed in separate classrooms for core/basic subject areas; (3) mainstream/inclusion models where English learners are placed in the same classrooms with non-English learners for English courses; (4) mainstream/inclusion models where English learners are placed in the same classrooms with non-English learners for core/basic subject areas; (5) Maintenance and/or developmental bilingual education where English learners are instructed in two languages in separate classrooms for all subjects; and (6) Dual language (twoway developmental bilingual education) where all students are instructed in two languages for all subjects.

Throughout the rest of the paper, we call schools that use the first two models "schools with sheltered classrooms".
} 
refugee-receiving schools are 19 percentage points more likely to be Haitian Creole speakers compared to incumbent students in other classrooms, yet this differences shrinks to 3 percentage points once we control for the LEP status of the incumbent students.

Refugees might have had different effects on different groups of incumbent students, and the Florida data provide us with the opportunity to study these differential relationships along several dimensions. This exercise is particularly important given the evidence that some student groups were more likely to be subjected to refugees (e.g., LEP students, students in schools with sheltered classrooms). First, we consider separately the effects of refugee concentration for Haitian-born students (12 percent of the incumbent population of the top refugee-receiving schools), other non-Haitian foreign-born students (9 percent), U.S.-born Haitian Creole speakers (29 percent), U.S. born black students who are not Haitian Creole speakers (38 percent), other nonblack U.S. born students (24 percent), LEP students (18 percent), and non-LEP students. We present this breakdown in the first panel of Table 8, which, for the sake of brevity, presents the estimated effects of refugee concentration on the performance index only ${ }^{17}$, and check the equivalence of incumbent student baseline characteristics for each student subgroup in Appendix Table 6. (The first panel of Table 9 repeats the same analysis looking at incumbent student mobility.) We observe that, across all groups of incumbent students, there is little evidence of a negative effect of refugees on incumbent students' test scores; while we observe the occasional negative estimated relationship, there are many more positive estimated relationships regarding student performance, and none of the performance estimates are distinguishable from zero. We also find little evidence that more refugees let to increased out-migration of students. Our general read of this evidence is that the concentration of refugees has no substantial negative effect on

\footnotetext{
${ }^{17}$ The effects estimated separately for test scores and disciplinary incidents are similar and available from the authors upon request).
} 
the short-term outcomes of incumbent students regardless of place of birth, spoken language, or race/ethnicity.

For Florida-born students, we can investigate differences in outcomes by maternal education levels, and we report these findings in the second panel of Table 8, with incumbent student mobility results presented in the second panel of Table 9, and baseline equivalency checks presented in Appendix Table 7. Because refugees tend to attend relatively low-SES schools, we break down the Florida incumbent students into those whose mothers have not completed their high school degrees, those whose mothers have a high school diploma but no further education, and those whose mothers have at least some college education. Regardless of maternal education level, we continue to find no evidence that refugee students substantially harmed the educational outcomes of any group of incumbent students.

Finally, the effects of a Haitian refugee influx on incumbent students might differ based on the share of existing Haitian students in the school, by grade level, school size (above or below the median size), or by the type of LEP instructional model the school employs. This might arise, for instance, if schools with sizable Haitian student populations are more likely to have established support systems for immigrants from Haiti such as Haitian-Creole speaking counselors, which might ease the transitional burden for the incoming refugees. In the third through sixth panels of Table 8, we break down the analysis by the share of existing HaitianCreole speakers (15 percent versus 40 percent, the $25^{\text {th }}$ percentile versus the $75^{\text {th }}$ percentile among top refugee receiving schools) and grade level in top refugee receiving schools whereas the third through sixth panels of Table 9 presents the mobility results and Appendix Table 8 checks the baseline equivalency of incumbent students. The estimated effects suggest no discernable differences in the effects of refugee concentration on student outcomes by school 
characteristics. While the occasional estimated coefficient is significantly positive or negative, the overall pattern of findings indicates a zero effect of refugees on incumbent students.

\subsection{Robustness Checks}

To identify the causal effect of refugee concentration on student outcomes, we rely on the within-school, across-grade variation in refugee concentration. An important challenge in this approach is the possible strategic placement of refugees across grades by school administrators. The findings we have presented thus far reveal that the OLS and IV estimators, the latter of which deal with this possible endogeneity using the naturally-occurring age distribution of entering refugees, yield comparable results, providing evidence that our OLS estimates are not contaminated by strategic placement of refugees. To further investigate the strategic placement of refugees across grades within schools, we also present a falsification exercise where we estimate (1) using student outcomes during the two years prior to the earthquake. If the crossgrade, within-school differences in refugee concentration were actually driven by endogenous factors, one would expect to find a relationship between the refugee concentration in 2010 and outcomes in 2007-08 and 2008-09. The findings, reported in Appendix Table 9, reveal no such placebo effect, providing further evidence against strategic placement. Not only are the estimated relationships between the would-be within-school refugee concentration in 2010 and preearthquake outcomes not statistically significant at conventional levels, but they are also very small in magnitude: For example, the estimates indicate that a one-percentage-point increase in the refugee concentration in a given grade is associated with tiny fractions of a standard deviation reductions in reading and math, respectively, in models that include school fixed effects and student covariates. 
Another important challenge in our empirical approach is the possibility that there is insufficient variation in refugee concentration across grades within schools, which would lead to zero effects of refugee concentration on incumbent student outcomes. Appendix Figure 1 portrays the within-school, cross-grade range in refugee concentration in each top refugeereceiving school, and shows that about a quarter of these schools ( 25 schools) have cross-grade range of at least 5 percentage points in refugee concentration, and about one-tenth (9 schools) have cross-grade range of at least 10 percentage points. Appendix Table 10 presents the OLS estimates of the effects of refugee concentration on student test scores and misbehavior in the first, second, and third year after the earthquake, estimated using school fixed effects and student covariates, restricting the sample to these high-variance schools. Once again, the findings reveal no adverse effect of refugees on the educational outcomes of incumbent students. In fact, when we use the schools with largest cross-cohort range in refugee concentration, we find a statistically significant positive effect of refugee concentration on incumbent student math scores in the first two years. ${ }^{18}$

Finally, we employ two alternative empirical strategies to our within-school analysis to check the robustness of our findings. First, in a difference-in-differences framework we explore the relationship between refugee concentration and within-student variation in student test scores and disciplinary incidents using student fixed effects, following individual students between the 2008-09 and 2011-12 school years. ${ }^{19}$ In particular, using OLS we estimate:

$$
Y_{i t s g}=v+\sigma R_{s g} * \text { Post }_{t}+\phi_{t}+\delta_{i}+\theta_{g}+\varepsilon_{i t s g}
$$

\footnotetext{
${ }^{18}$ In Appendix Table 11, we also repeat the same analysis excluding outlier top refugee-receiving schools with refugee concentrations larger than 5 percent, and reach the same conclusion.

${ }^{19}$ In this exercise, we restrict the sample to students that we observe in all 4 years between 2008-09 and 2011-12. We lack power to estimate this model with multiple pre-earthquake years of data.
} 
where Post $_{t}$ is a vector of year dummies for Spring 2010, 2010-11, and 2011-12 school years, and $\phi_{t}, \delta_{i}$, and $\theta_{g}$ are year, student, and grade fixed effects. Appendix Table 12 presents the results, and shows that refugee concentration increases reading performance among incumbent students, but it also leads to an increase in disciplinary incidents. We do not find any significant effects of refugees on incumbent student math scores.

Second, the birth-school match enables us to identify sets of siblings in our Florida-born student sample, and we use these identifiers to estimate the effect of refugee concentration on incumbent student outcomes in a family fixed effects framework. In particular, using the sample of Florida born students who were attending a Florida public school in Fall 2009 and who had at least one sibling in the school system, we estimate

$$
Y_{i t f g}=\alpha+\beta R_{s g}+\delta_{f}+\theta_{g}+\varepsilon_{i t f g}
$$

where $\delta_{f}$ is family fixed effects. Appendix Table 13 presents the effects on incumbent student outcomes in Spring 2010, 2010-11, and 2011-12 without family fixed effects and student covariates (columns (I)), including family fixed effects (columns (II)), and including both family fixed effects and student covariates (columns (III)). In our preferred specification where we control for both family fixed effects and student covariates, we do not find any significant effect of refugee concentration on student test scores or disciplinary incidents.

\section{Concluding Remarks}

Understanding the effects of refugees on incumbent communities is more important than ever as the world faces the second largest refugee crisis in a century. In this study, we present the first evidence on the effects of a major refugee influx on the educational outcomes of incumbent students using the wave of Haitian refugees who entered Florida public schools after the devastating earthquake in January 2010. We find no significant adverse effect of refugees on the 
educational outcomes of incumbent students including test scores, disciplinary incidents, and student mobility across schools. While we tend to find many more positive estimates than negative estimates, the weight of the evidence indicates that refugees have a precisely estimated zero effect on incumbent students' outcomes, both immediately following the arrival of refugees and up to two years afterward.

That said, there are several factors that might hinder the generalizability of our findings to other contexts. There is an established and sizeable Haitian immigrant population in Florida and as we have shown earlier Haitian refugees enrolled in schools with considerable Haitian student populations. These schools might already have support systems in place to help recent immigrants from Haiti such as Haitian Creole speaking counselors, and hence might be more prepared to accommodate an influx of Haitian refugees, minimizing the adverse effects on existing students. Such support systems might not exist in other contexts (such as the Syrian refugee crisis in Europe) and hence the negative externalities of refugees on incumbent students might be more severe. That said, recall that Haitian Creole speakers were still a small minority of incumbent students in almost every refugee-receiving school prior to the 2010 earthquake. Just six percent of the incumbent student body of the typical refugee-receiving school spoke Haitian Creole, and only half of all Haitian immigrants (not counting native-born Haitian Creole speakers) are considered limited English proficient. Limited English proficient Haitian Creole speakers account for more than ten percent of the incumbent student body population in only 78 schools, and more than twenty percent of the incumbent student population in just 26 schools. Therefore, it is unlikely that there existed substantial educational or social services for Haitian immigrants in all but a relative handful of schools. 
In summary, there appears to be little evidence that a sizeable influx of refugees has short-term negative consequences on native students. Taken together with new evidence by Evans and Fitzgerald (2017) that after a period of adjustment, refugees have similar economic outcomes, across several dimensions, to comparison U.S.-born natives, and ultimately pay more in taxes than they receive in benefit, these findings indicate that the potential negative externalities associated with refugee admissions are likely lower than some may worry. 


\section{References}

Akgündüz, Yusuf Emre, Marcel van den Berg, and Wolter Hassink (2015), “The Impact of Refugee Crises on Host Labor Markets: The Case of the Syrian Refugee Crisis in Turkey”. Institute for the Study of Labor (IZA, Bonn) Discussion Paper No 8841.

Angrist, Joshua D. and Kevin Lang (2004), “Does school integration generate peer effects? Evidence from Boston’s Metco program”, American Economic Review 94(5), 16131634.

Beaman, Lori (2012). “Social Networks and the Dynamics of Labour Maket Outcomes:

Evidence from Refugees Resettled in the U.S.” Review of Economic Studies 79(1): 128-161.

Betts, Julian R. (1998). “Educational Crowding Out: Do Immigrants Affect the Educational Attainment of American Minorities?” in Daniel S. Hamermesh and Frank D. Bean (Eds.), Help or Hindrance? The Economic Implications of Immigration for African- Americans, New York: Russell Sage Foundation.

Betts, Julian R. and Fairlie, Robert W. (2003). “Does Immigration Induce 'Native Flight’ from Public Schools into Private Schools.” Journal of Public Economics, 87(5-6), 987-1012.

Borjas, G. J. (2013). “The analytics of the wage effect of immigration," IZA Journal of Migration, 2(1), 22.

Brunello, Giorgio and Lorenzo Rocco (2013). "The effect of immigration on the school performance of natives: Cross country evidence using PISA test scores”. Economics of Education Review, 32: 234-246.

Card, David (2001). “Immigrant Inflows, Native Outflows, and the Local Market Impacts of Higher Immigration”. Journal of Labor Economics, 19(1), 22-64/

Cascio, Elizabeth U. and Ethan G. Lewis (2012). "Cracks in the Melting Pot: Immigration, 
School Choice, and Segregation." American Economic Journal: Economic Policy, 4(3): 91-117.

Connor, Phillip (2010). “Explaining the Refugee Gap: Economic Outcomes of Refugees versus Other Immigrants”. Journal of Refugee Studies 23(2): 377-397.

Cortes, K. E. (2004). “Are Refugees Different from Economic Immigrants? Some Empirical Evidence on the Heterogeneity of Immigrant Groups in the United States.” The Review of Economics and Statistics, 86 (2): 465-80.

Dustmann, C., A. Glitz, and T. Frattini (2008). "The labour market impact of immigration," Oxford Review of Economic Policy, 24(3), 477 - 494.

Evans, William and Daniel Fitzgerald (2017). “The Economic and Social Outcomes of Refugees in the United States: Evidence from the ACS.” NBER working paper 23498.

Figlio, David, Jonathan Guryan, Krzysztof Karbownik, and Jeffrey Roth (2014). “The Effect of Poor Neonatal Health on Children's Cognitive Development.” American Economic Review, 104(12), 3921 - 3955.

Geay, Charlotte, Sandra McNally and Shqiponja Telhaj (2013), “Non-native speakers of English in the classroom: What are the effects on pupil performance?”. The Economic Journal 123(570), F281-F307.

Gerdes, Christer (2010), “Does immigration induce ‘native flight’ from public schools? Evidence from a large scale voucher program”. The Annals of Regional Science, 50(2): 645-666.

Gould, Eric D., Victor Lavy and M. Daniele Paserman (2009), “Does immigration affect the long-term educational outcomes of natives? Quasi-experimental evidence”, The Economic Journal 119(540), 1243-1269.

Hanushek, Eric A., John F. Kain and Steven G. Rivkin (2009), “New evidence about Brown v. 
Board of Education: The complex effects of school racial composition on achievement”, Journal of Labor Economics 27(3), 349-383.

Hoxby, Caroline M. (2000), "Peer effects in the classroom: Learning from gender and race Variation”. National Bureau of Economic Research (NBER, Cambridge MA) Working Paper No. 7867.

Hunt, Jennifer (2016), “The Impact of Immigration on the Educational Attainment of Natives”. Journal of Human Resources, doi: 10.3368/jhr.52.4.0115-6913R1.

Jensen, Peter and Astrid Wurtz-Rasmussen (2011), “The effect of immigrant concentration in schools on native and immigrant children's reading and math skills”. Economics of Education Review 30(6), 1503-1515.

Ohinata, Asako and Jan C. van Ours (2013). “How Immigrant Children Affect the Academic Achievement of Native Dutch Children”. The Economic Journal 123(570), F308-F331. Potocky-Tripodi, Miriam (2004). “The Role of Social Capital in Immigrant and Refugee Economic Adaptation”. Journal of Social Service Research 31(1), 59-91. Schindler-Rangvid, Beatrice (2006), “Living and learning separately? Ethnic segregation of school children in Copenhagen”, Urban Studies 44(7), 1329-1354.

Schneeweis, Nicole (2015). “Immigrant concentration in schools: Consequences for native and migrant students”. Labour Economics (35), 63-76. 


\section{Figure 1}

Distribution of Haitian Students Entering Florida Public Schools in Spring Semester, by Month, between 2003-04 and 2011-12

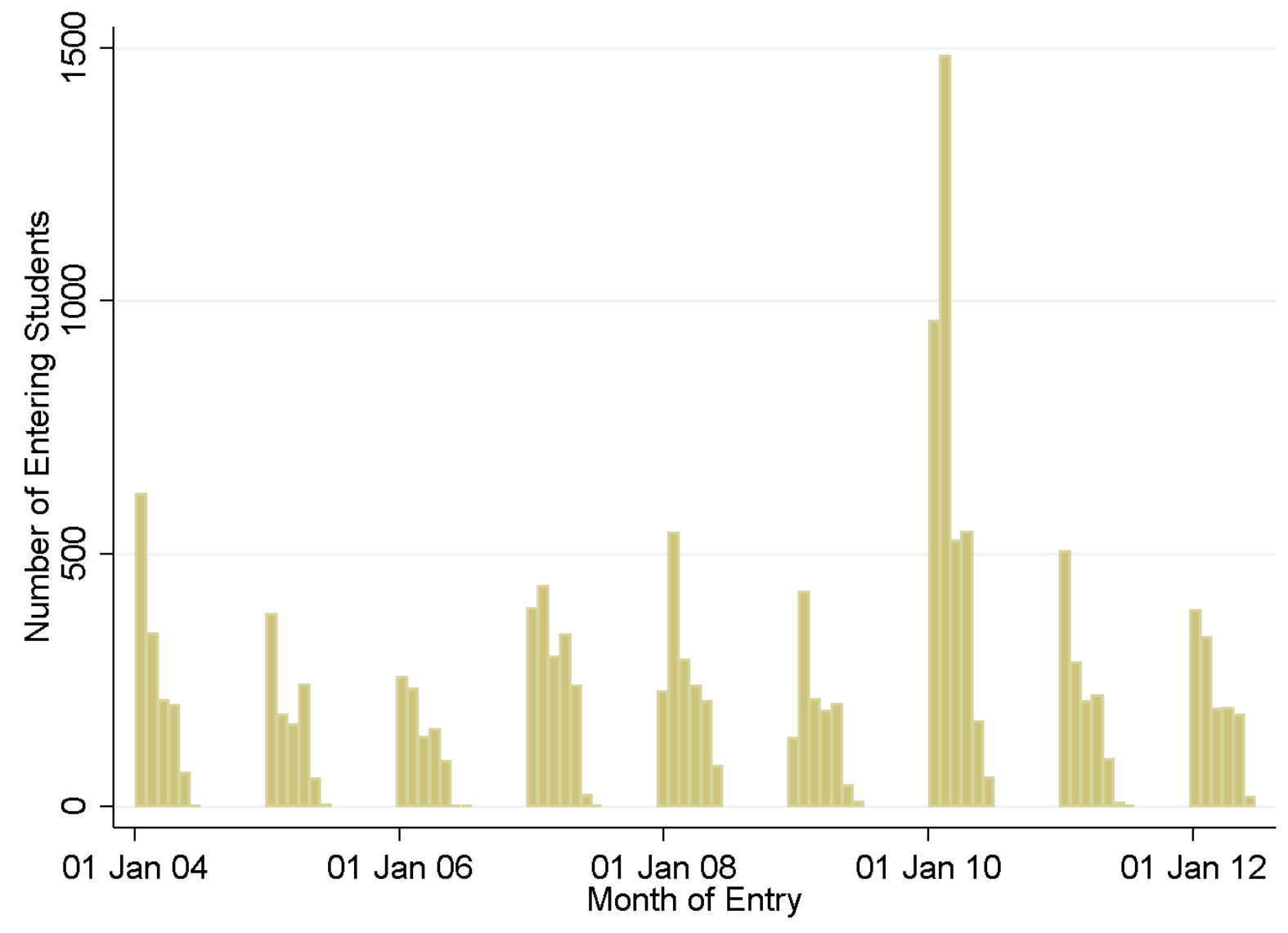


Figure 2

Top Haitian Refugee-Receiving Schools in Florida

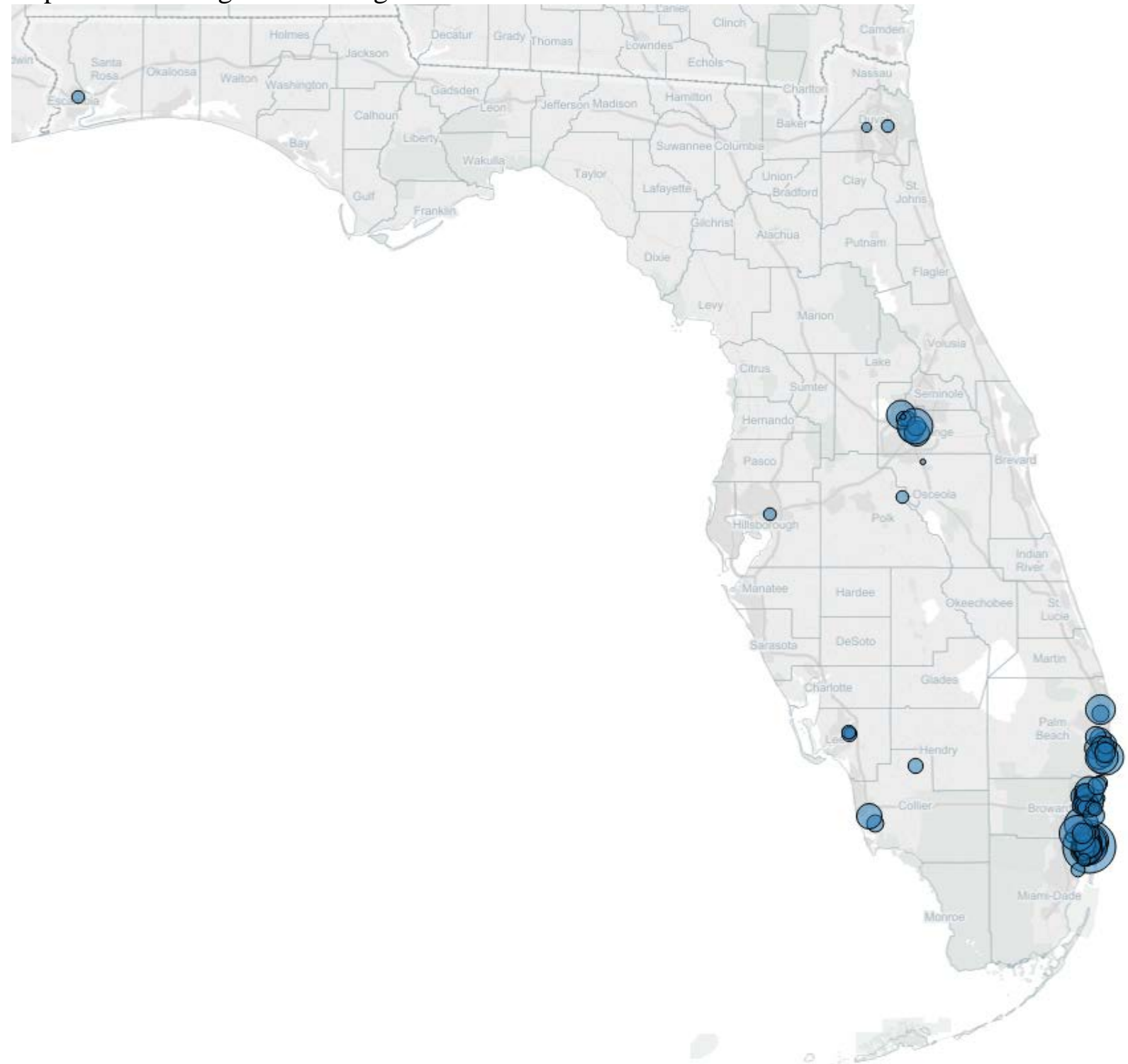

Notes: The size of each bubble is proportional to the number of arriving Haitian refugees at the school. 
Table 1

Number of Schools by Refugee Concentration in Spring 2010

\begin{tabular}{lcc}
\hline & Elementary Schools & $\begin{array}{c}\text { Middle and High } \\
\text { Schools }\end{array}$ \\
\hline No refugees & 1,523 & 991 \\
& {$[43.3 \%]$} & {$[41.9 \%]$} \\
Less than $1 \%$ & 1,942 & 1,329 \\
& {$[55.2 \%]$} & {$[56.1 \%]$} \\
Between 1\% and 5\% & 52 & 44 \\
& {$[1.5 \%]$} & {$[1.9 \%]$} \\
More than 5\% & 1 & 3 \\
& {$[0.1 \%]$} & {$[0.1 \%]$} \\
\hline $\begin{array}{l}\text { Notes: Refugee concentration is calculated as the number of entering refugees from Haiti between January 12, 2010 } \\
\text { and the end of the Spring semester in 2009-10 school year, divided by the total number of incumbent students at }\end{array}$ \\
each school. Percentage of schools in each category given in brackets.
\end{tabular}


Table 2

Differences in Student Characteristics between Haitian Refugees and Other Immigrant Groups

\begin{tabular}{lccc}
\hline & & Other Immigrants & $\begin{array}{c}\text { Haitian Immigrants } \\
\text { in Prior Spring } \\
\text { Semesters }\end{array}$ \\
\hline Free/reduced lunch eligible & 0.887 & 0.629 & 0.722 \\
& $(0.316)$ & $(0.483)$ & $(0.448)$ \\
Limited English proficient & 0.909 & 0.739 & 0.522 \\
& $(0.288)$ & $(0.439)$ & $(0.500)$ \\
English non-native & 0.940 & 0.808 & 0.958 \\
Special education status & $(0.238)$ & $(0.394)$ & $(0.200)$ \\
& 0.006 & 0.022 & 0.004 \\
Age (in months) & $(0.075)$ & $(0.146)$ & $(0.061)$ \\
& 144.2 & 135.8 & 148.1 \\
& $(46.43)$ & $(44.33)$ & $(48.44)$ \\
& & & 7,898 \\
\hline
\end{tabular}

Notes: Standard deviations in parentheses. The third column includes the Haitian immigrants entering the Florida public school system in the Spring semesters of school years between 2003-04 and 2008-09 school years. For the purposes of this table, limited English proficiency status is the first recorded status upon entry into Florida public schools. 
Table 3

Student Characteristics in Refugee-Receiving Schools versus Others, Fall 2009

\begin{tabular}{|c|c|c|}
\hline & $\begin{array}{l}\text { Refugee-Receiving } \\
\text { Schools }\end{array}$ & Other Schools \\
\hline \multirow[t]{2}{*}{ Haitian Creole speaker } & 0.063 & 0.007 \\
\hline & $(0.243)$ & $(0.083)$ \\
\hline \multirow[t]{2}{*}{ Born in Haiti } & 0.026 & 0.002 \\
\hline & $(0.160)$ & $(0.049)$ \\
\hline \multirow[t]{2}{*}{ Foreign born } & 0.134 & 0.072 \\
\hline & $(0.341)$ & $(0.258)$ \\
\hline \multirow[t]{2}{*}{ Prior year reading score } & -0.088 & 0.030 \\
\hline & $(0.985)$ & $(0.985)$ \\
\hline \multirow[t]{2}{*}{ Prior year math score } & -0.044 & 0.030 \\
\hline & $(0.993)$ & $(0.978)$ \\
\hline \multirow[t]{2}{*}{ Prior year disciplinary incident } & 0.096 & 0.070 \\
\hline & $(0.295)$ & $(0.26)$ \\
\hline \multirow[t]{2}{*}{ FRPL eligible } & 0.593 & 0.541 \\
\hline & $(0.491)$ & $(0.498)$ \\
\hline \multirow[t]{2}{*}{ White } & 0.330 & 0.513 \\
\hline & $(0.470)$ & $(0.500)$ \\
\hline \multirow[t]{2}{*}{ Hispanic } & 0.302 & 0.231 \\
\hline & $(0.459)$ & $(0.422)$ \\
\hline \multirow[t]{2}{*}{ Black } & 0.302 & 0.185 \\
\hline & $(0.459)$ & $(0.388)$ \\
\hline \multirow[t]{2}{*}{ Asian } & 0.028 & 0.025 \\
\hline & $(0.165)$ & $(0.156)$ \\
\hline \multirow[t]{2}{*}{ Limited English proficient } & 0.108 & 0.072 \\
\hline & $(0.310)$ & $(0.258)$ \\
\hline \multirow[t]{2}{*}{ English non-native } & 0.353 & 0.220 \\
\hline & $(0.478)$ & $(0.414)$ \\
\hline \multirow[t]{2}{*}{ Special education student } & 0.129 & 0.145 \\
\hline & $(0.335)$ & $(0.352)$ \\
\hline \multirow[t]{2}{*}{ Gifted student } & 0.058 & 0.062 \\
\hline & $(0.233)$ & $(0.241)$ \\
\hline \multirow[t]{2}{*}{ Age (in months) } & 149.5 & 134.9 \\
\hline & $(45.52)$ & $(44.68)$ \\
\hline \multirow[t]{2}{*}{ Mother with less than HS degree } & 0.239 & 0.214 \\
\hline & $(0.426)$ & $(0.410)$ \\
\hline \multirow[t]{2}{*}{ Mother with some college education } & 0.378 & 0.409 \\
\hline & $(0.485)$ & $(0.492)$ \\
\hline \multirow[t]{2}{*}{ Mother married } & 0.591 & 0.631 \\
\hline & $(0.492)$ & $(0.483)$ \\
\hline
\end{tabular}

Notes: Standard deviations in parentheses. All refugee-receiving schools include 865,399 unique student observations, 473,465 unique prior year test scores, and 438,187 unique Florida born students for whom we observe maternal characteristics whereas the second column includes 1,648,409 unique student observations, 827,653 unique test score observations, and 880,933 unique Florida born students. 
Table 4

Within-Cohort Refugee Concentration and Existing Student and Teacher Characteristics

\begin{tabular}{|c|c|c|c|c|}
\hline & \multicolumn{2}{|c|}{$\begin{array}{l}\text { All Refugee-Receiving } \\
\text { Schools } \\
\end{array}$} & \multicolumn{2}{|c|}{$\begin{array}{c}\text { Top Refugee-Receiving } \\
\text { Schools }\end{array}$} \\
\hline & (I) & (II) & (I) & (II) \\
\hline School fixed effects & No & Yes & No & Yes \\
\hline \multirow[t]{2}{*}{ Haitian Creole speaker } & $0.060^{* * *}$ & 0.001 & $0.020^{* * *}$ & -0.0001 \\
\hline & $(0.010)$ & $(0.001)$ & $(0.007)$ & $(0.002)$ \\
\hline \multirow[t]{2}{*}{ Born in Haiti } & $0.030^{* * *}$ & 0.001 & $0.015^{* * *}$ & 0.002 \\
\hline & $(0.004)$ & $(0.001)$ & $(0.005)$ & $(0.001)$ \\
\hline \multirow[t]{2}{*}{ Prior year reading score } & $-0.094^{* * *}$ & -0.006 & -0.021 & -0.004 \\
\hline & $(0.017)$ & $(0.005)$ & $(0.012)$ & $(0.007)$ \\
\hline \multirow[t]{2}{*}{ Prior year math score } & $-0.090^{* * *}$ & -0.006 & $-0.025^{*}$ & -0.006 \\
\hline & $(0.016)$ & $(0.006)$ & $(0.014)$ & $(0.008)$ \\
\hline \multirow[t]{2}{*}{ Prior year disciplinary incident } & $0.005^{*}$ & 0.001 & $-0.005^{* *}$ & $-0.002^{*}$ \\
\hline & $(0.003)$ & $(0.001)$ & $(0.002)$ & $(0.001)$ \\
\hline \multirow[t]{2}{*}{ FRPL eligible } & $0.055^{* * *}$ & 0.001 & -0.002 & -0.001 \\
\hline & $(0.013)$ & $(0.002)$ & $(0.005)$ & $(0.002)$ \\
\hline \multirow[t]{2}{*}{ White } & $-0.075^{* * *}$ & $-0.001^{*}$ & -0.004 & 0.0001 \\
\hline & $(0.015)$ & $(0.001)$ & $(0.003)$ & $(0.001)$ \\
\hline \multirow[t]{2}{*}{ Hispanic } & $-0.024^{* * *}$ & 0.001 & $-0.006^{* * *}$ & -0.001 \\
\hline & $(0.006)$ & $(0.001)$ & $(0.002)$ & $(0.001)$ \\
\hline \multirow[t]{2}{*}{ Black } & $0.106^{* * *}$ & 0.001 & $0.012^{*}$ & 0.002 \\
\hline & $(0.020)$ & $(0.001)$ & $(0.006)$ & $(0.001)$ \\
\hline \multirow[t]{2}{*}{ Asian } & $-0.003^{* * *}$ & 0.0002 & $-0.001^{* * *}$ & -0.00004 \\
\hline & $(0.001)$ & $(0.0002)$ & $(0.0004)$ & $(0.0002)$ \\
\hline \multirow[t]{2}{*}{ Foreign born } & $0.028^{* * *}$ & $0.002^{* *}$ & $0.013^{* * *}$ & 0.002 \\
\hline & $(0.003)$ & $(0.001)$ & $(0.003)$ & $(0.001)$ \\
\hline \multirow{2}{*}{ Limited English proficient } & $0.024^{* * *}$ & 0.0002 & $0.015^{* * *}$ & 0.001 \\
\hline & $(0.003)$ & $(0.001)$ & $(0.004)$ & $(0.002)$ \\
\hline \multirow[t]{2}{*}{ English non-native } & $0.043^{* * *}$ & 0.001 & $0.017^{* * *}$ & -0.001 \\
\hline & $(0.008)$ & $(0.001)$ & $(0.004)$ & $(0.001)$ \\
\hline \multirow[t]{2}{*}{ Special education student } & $-0.004^{* * *}$ & $-0.001^{*}$ & $-0.004^{* * *}$ & -0.001 \\
\hline & $(0.001)$ & $(0.001)$ & $(0.001)$ & $(0.001)$ \\
\hline \multirow[t]{2}{*}{ Gifted student } & $-0.005^{* * *}$ & -0.0004 & -0.001 & -0.001 \\
\hline & $(0.002)$ & $(0.001)$ & $(0.001)$ & $(0.001)$ \\
\hline \multirow[t]{2}{*}{ Age (in months) } & $0.517^{* * *}$ & $0.094^{*}$ & 0.327 & 0.054 \\
\hline & $(0.128)$ & $(0.049)$ & $(0.234)$ & $(0.071)$ \\
\hline \multirow[t]{2}{*}{ Mother -less than HS diploma } & $0.041^{* * *}$ & 0.0003 & 0.006 & -0.001 \\
\hline & $(0.006)$ & $(0.001)$ & $(0.006)$ & $(0.002)$ \\
\hline \multirow[t]{2}{*}{ Mother - some college } & $-0.057^{* * *}$ & -0.001 & -0.007 & -0.0003 \\
\hline & $(0.008)$ & $(0.001)$ & $(0.007)$ & $(0.002)$ \\
\hline \multirow[t]{3}{*}{ Mother married } & $-0.058^{* * *}$ & -0.001 & -0.002 & 0.0001 \\
\hline & $(0.008)$ & $(0.002)$ & $(0.005)$ & $(0.002)$ \\
\hline & \multicolumn{4}{|c|}{ Average Teacher Characteristics } \\
\hline \multirow[t]{2}{*}{ Average teacher experience } & $-0.124^{* * *}$ & -0.008 & $-0.083^{* *}$ & -0.009 \\
\hline & $(0.037)$ & $(0.041)$ & $(0.038)$ & $(0.049)$ \\
\hline$\%$ novice teachers & 0.001 & 0.001 & 0.001 & 0.002 \\
\hline & $(0.001)$ & $(0.002)$ & $(0.002)$ & $(0.002)$ \\
\hline \% early career teachers & $0.004^{* * *}$ & -0.003 & 0.003 & -0.003 \\
\hline
\end{tabular}




\begin{tabular}{llccc} 
& $(0.002)$ & $(0.002)$ & $(0.002)$ & $(0.003)$ \\
\% mid-career teachers & 0.001 & -0.0003 & 0.003 & -0.003 \\
\% late career teachers & $(0.002)$ & $(0.002)$ & $(0.002)$ & $(0.003)$ \\
& $-0.006^{* *}$ & 0.002 & -0.003 & 0.001 \\
\% teachers with advanced deg. & $(0.003)$ & $(0.002)$ & $(0.003)$ & $(0.003)$ \\
& -0.001 & 0.001 & -0.002 & 0.002 \\
& $(0.002)$ & $(0.002)$ & $(0.002)$ & $(0.002)$ \\
\hline
\end{tabular}

Notes: Robust standard errors clustered at the school level are given in parentheses. Each entry represents the estimated correlation between within-cohort refugee concentration and the corresponding student and average teacher attribute at the grade level with (columns (I)) and without (columns (II)) school fixed effects. Regressions using all refugee-receiving schools include 865,399 unique student observations, or 473,465 unique prior year test scores, or 438,187 Florida born students for whom maternal characteristics are available, or 4,493 school-by-grade average teacher characteristics. Regressions using the top refugee-receiving schools include 72,407 unique student observations, or 39,678 unique prior year test scores, or 36,309 Florida born students for whom maternal characteristics are available, or 524 school-by-grade average teacher characteristics. Novice teachers are defined as teachers with no prior experience; early career teachers are identified as those with 1-3 years of experience; midcareer teachers are identified as teachers with 4-10 years of experience, and late career teachers are teachers with more than 10 years of experience. ${ }^{*} p<0.10,{ }^{* *} p<0.05,{ }^{* * *} p<0.01$. 
Table 5

Within-Cohort Refugee Concentration and Existing Student Test Scores and Misbehavior, OLS Results

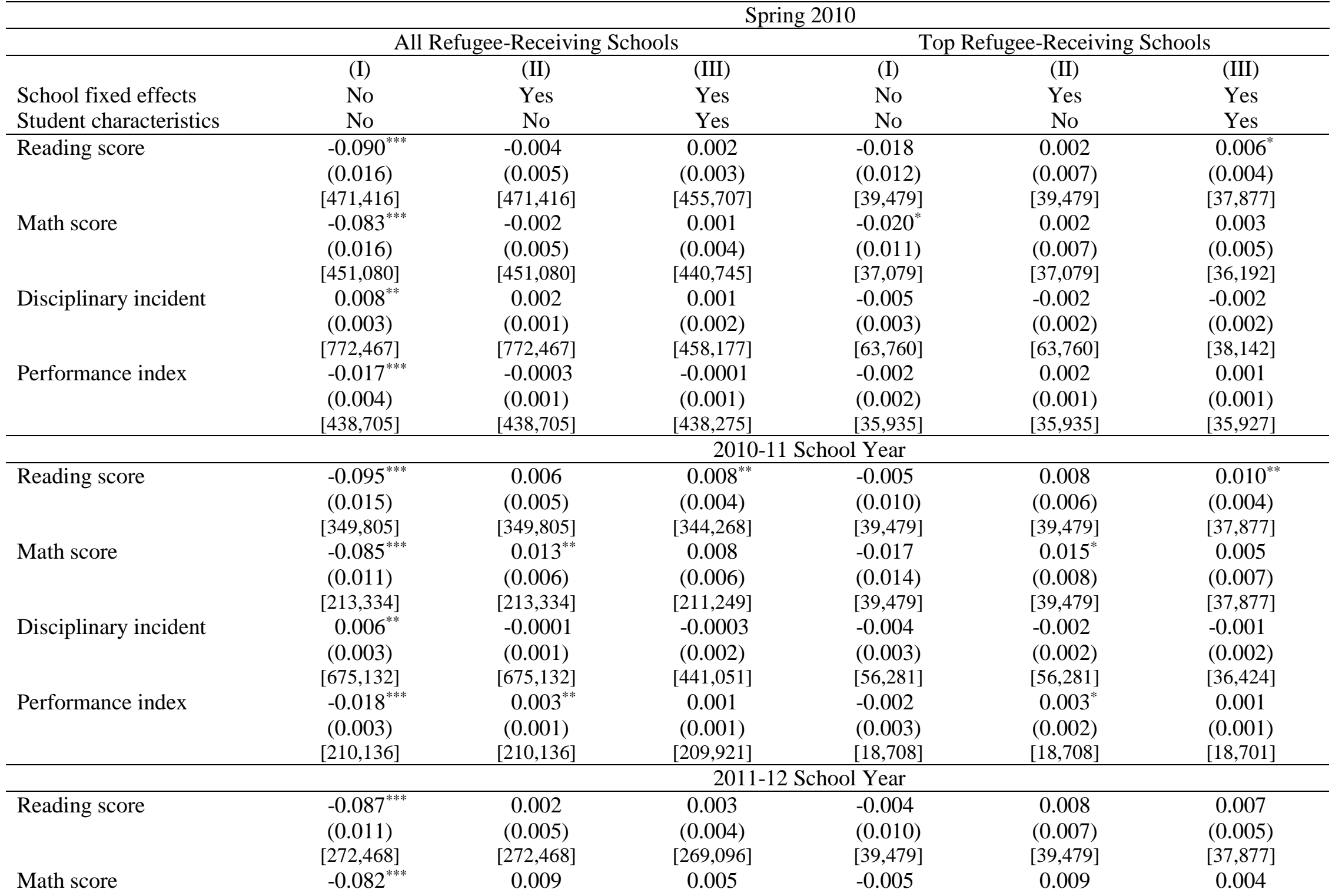




\begin{tabular}{|c|c|c|c|c|c|c|}
\hline & $(0.011)$ & $(0.006)$ & $(0.006)$ & $(0.011)$ & $(0.008)$ & $(0.008)$ \\
\hline & {$[145,685]$} & {$[145,685]$} & {$[144,546]$} & {$[39,479]$} & {$[39,479]$} & {$[37,877]$} \\
\hline \multirow{3}{*}{ Disciplinary incident } & $0.006^{* *}$ & -0.001 & -0.001 & -0.004 & -0.002 & -0.0003 \\
\hline & $(0.003)$ & $(0.001)$ & $(0.002)$ & $(0.003)$ & $(0.002)$ & $(0.002)$ \\
\hline & {$[579,682]$} & {$[579,682]$} & {$[405,726]$} & {$[49,675]$} & {$[49,675]$} & {$[33,255]$} \\
\hline \multirow[t]{3}{*}{ Performance index } & $-0.017^{* * *}$ & $0.002^{* *}$ & 0.001 & -0.0002 & $0.003^{*}$ & 0.001 \\
\hline & $(0.002)$ & $(0.001)$ & $(0.001)$ & $(0.003)$ & $(0.001)$ & $(0.001)$ \\
\hline & {$[143,444]$} & {$[143,444]$} & {$[143,297]$} & {$[13,256]$} & {$[13,256]$} & {$[13,249]$} \\
\hline
\end{tabular}

Notes: Robust standard errors clustered at the school level are given in parentheses. Numbers in brackets represent the number of observations used in the corresponding specification. Each column represents the effect of within-cohort refugee concentration in Spring 2010 on the test scores and disciplinary incidents of incumbent students in Spring 2010, 2010-11, and 2011-12, estimated using OLS. Columns labeled as (I) and (II) only include students with non-missing lagged outcome variable for the outcome specified. Columns labeled as (III) introduce the student characteristics (other than maternal attributes) listed in Table 4. ${ }^{*} p<0.10,{ }^{* *} p<0.05,{ }^{* * * *} p<0.01$. 
Table 6

Within-Cohort Refugee Concentration and Incumbent Student Mobility, OLS Results

\begin{tabular}{|c|c|c|c|}
\hline & \multicolumn{3}{|c|}{ By Fall $2010 \ldots$} \\
\hline & \multicolumn{3}{|c|}{ All Refugee-Receiving Schools } \\
\hline & (I) & (II) & (III) \\
\hline School fixed effects & No & Yes & Yes \\
\hline Student characteristics & No & No & Yes \\
\hline \multirow[t]{2}{*}{ Moved to another public school } & $0.015^{* * *}$ & 0.003 & 0.001 \\
\hline & $(0.003)$ & $(0.003)$ & $(0.004)$ \\
\hline \multirow[t]{3}{*}{ Left FL public schools } & 0.0003 & $0.003^{* *}$ & 0.0002 \\
\hline & $(0.001)$ & $(0.001)$ & $(0.001)$ \\
\hline & \multicolumn{3}{|c|}{ Top Refugee-Receiving Schools } \\
\hline \multirow[t]{2}{*}{ Moved to another public school } & 0.002 & 0.002 & 0.001 \\
\hline & $(0.003)$ & $(0.003)$ & $(0.005)$ \\
\hline \multirow[t]{4}{*}{ Left FL public schools } & $0.003^{*}$ & 0.002 & -0.001 \\
\hline & $(0.002)$ & $(0.002)$ & $(0.001)$ \\
\hline & \multicolumn{3}{|c|}{ By Fall 2011... } \\
\hline & \multicolumn{3}{|c|}{ All Refugee-Receiving Schools } \\
\hline \multirow[t]{2}{*}{ Moved to another public school } & $0.016^{* * *}$ & 0.004 & 0.0002 \\
\hline & $(0.003)$ & $(0.002)$ & $(0.003)$ \\
\hline \multirow{3}{*}{ Left FL public schools } & $-0.003^{* *}$ & -0.0002 & $-0.003^{*}$ \\
\hline & $(0.001)$ & $(0.002)$ & $(0.002)$ \\
\hline & \multicolumn{3}{|c|}{ Top Refugee-Receiving Schools } \\
\hline \multirow[t]{2}{*}{ Moved to another public school } & 0.0003 & 0.003 & 0.0001 \\
\hline & $(0.002)$ & $(0.003)$ & $(0.003)$ \\
\hline \multirow[t]{2}{*}{ Left FL public schools } & 0.001 & -0.002 & $-0.005^{* *}$ \\
\hline & $(0.001)$ & $(0.002)$ & $(0.003)$ \\
\hline
\end{tabular}

Notes: Robust standard errors clustered at the school level are given in parentheses. Each column represents the effect of within-cohort refugee concentration in Spring 2010 on the mobility of incumbent students by Fall 2010, and by Fall 2011. Regressions using all refugee-receiving schools include 772,467 unique student observations. Regressions using the top refugee-receiving schools include 72,407 unique student observations. Columns labeled as (II) introduce the student characteristics (other than maternal attributes) listed in Table $4 .{ }^{*} p<0.10,{ }^{* *} p<0.05,{ }^{* * *} p$ $<0.01$. 
Table 7

Within-Cohort Differences in Existing Student Characteristics between Refugee-Receiving and Other Classrooms

\begin{tabular}{|c|c|c|c|c|}
\hline & \multicolumn{2}{|c|}{ All Refugee-Receiving Schools } & \multicolumn{2}{|c|}{$\begin{array}{c}\text { Top Refugee-Receiving } \\
\text { Schools }\end{array}$} \\
\hline & (I) & (II) & (I) & (II) \\
\hline \multirow{2}{*}{$\begin{array}{l}\text { School-by-grade fixed effects } \\
\text { Control for limited English prof }\end{array}$} & Yes & Yes & Yes & Yes \\
\hline & No & Yes & No & Yes \\
\hline \multirow{2}{*}{ Haitian Creole speaker } & $0.095^{* * *}$ & $0.040^{* * *}$ & $0.189^{* * *}$ & $0.028^{* * *}$ \\
\hline & $(0.006)$ & $(0.004)$ & $(0.017)$ & $(0.010)$ \\
\hline \multirow[t]{2}{*}{ Born in Haiti } & $0.105^{* * *}$ & $0.051^{* * *}$ & $0.257^{* * *}$ & $0.065^{* * *}$ \\
\hline & $(0.007)$ & $(0.004)$ & $(0.021)$ & $(0.011)$ \\
\hline \multirow[t]{2}{*}{ Prior year reading score } & $-0.438^{* * *}$ & $-0.246^{* * *}$ & $-0.487^{* * *}$ & $-0.268^{* * *}$ \\
\hline & $(0.021)$ & $(0.018)$ & $(0.058)$ & $(0.051)$ \\
\hline \multirow[t]{2}{*}{ Prior year math score } & $-0.404^{* * *}$ & $-0.248^{* * *}$ & $-0.492^{* * *}$ & $-0.331^{* * *}$ \\
\hline & $(0.020)$ & $(0.018)$ & $(0.056)$ & $(0.047)$ \\
\hline \multirow[t]{2}{*}{ Prior year disciplinary incident } & 0.0003 & $0.009^{* * *}$ & 0.002 & $0.020^{* * *}$ \\
\hline & $(0.004)$ & $(0.003)$ & $(0.006)$ & $(0.006)$ \\
\hline \multirow[t]{2}{*}{ FRPL eligible } & $0.055^{* * *}$ & $0.016^{* * *}$ & $0.021^{* * *}$ & -0.001 \\
\hline & $(0.004)$ & $(0.004)$ & $(0.007)$ & $(0.006)$ \\
\hline \multirow[t]{2}{*}{ White } & $-0.054^{* * *}$ & $-0.007^{* *}$ & $-0.028^{* * *}$ & -0.003 \\
\hline & $(0.003)$ & $(0.003)$ & $(0.007)$ & $(0.004)$ \\
\hline \multirow[t]{2}{*}{ Hispanic } & $0.055^{* * *}$ & $-0.020^{* * *}$ & 0.008 & $-0.032^{* * *}$ \\
\hline & $(0.005)$ & $(0.004)$ & $(0.009)$ & $(0.009)$ \\
\hline \multirow[t]{2}{*}{ Black } & 0.004 & $0.031^{* * *}$ & $0.023^{* *}$ & $0.034^{* * *}$ \\
\hline & $(0.004)$ & $(0.004)$ & $(0.010)$ & $(0.009)$ \\
\hline \multirow[t]{2}{*}{ Asian } & 0.002 & $-0.004^{* * *}$ & 0.003 & 0.0001 \\
\hline & $(0.001)$ & $(0.001)$ & $(0.002)$ & $(0.002)$ \\
\hline \multirow[t]{2}{*}{ Foreign born } & $0.172^{* * *}$ & $0.042^{* * *}$ & $0.288^{* * *}$ & $0.061^{* * *}$ \\
\hline & $(0.008)$ & $(0.004)$ & $(0.019)$ & $(0.010)$ \\
\hline \multirow{2}{*}{ Limited English proficient } & $0.275^{* * *}$ & & $0.417^{* * *}$ & \\
\hline & $(0.012)$ & & $(0.027)$ & \\
\hline \multirow[t]{2}{*}{ English non-native } & $0.176^{* * *}$ & $0.010^{* * *}$ & $0.230^{* * *}$ & -0.004 \\
\hline & $(0.008)$ & $(0.004)$ & $(0.019)$ & $(0.009)$ \\
\hline \multirow[t]{2}{*}{ Special education student } & $-0.019^{* * *}$ & $-0.008^{* *}$ & $-0.032^{* * *}$ & -0.003 \\
\hline & $(0.003)$ & $(0.003)$ & $(0.008)$ & $(0.009)$ \\
\hline \multirow[t]{2}{*}{ Gifted student } & $-0.037^{* * *}$ & $-0.028^{* * *}$ & $-0.031^{* * *}$ & $-0.022^{* * *}$ \\
\hline & $(0.002)$ & $(0.002)$ & $(0.007)$ & $(0.006)$ \\
\hline \multirow{2}{*}{ Age (in months) } & $0.492^{* * *}$ & $0.363^{* * *}$ & $0.725^{* * *}$ & $0.524^{* *}$ \\
\hline & $(0.115)$ & $(0.093)$ & $(0.267)$ & $(0.260)$ \\
\hline
\end{tabular}

Notes: Robust standard errors clustered at the school level are given in parentheses. Each entry represents the estimated difference in student characteristics between incumbent students in refugee-receiving classrooms and other, controlling for school-by-grade fixed effects, without (columns (I)) and with (columns (II)) LEP status in all refugee-receiving schools and top refugee-receiving schools. Regressions using all refugee-receiving schools include 865,399 unique student observations or 473,465 unique prior year test scores. Regressions using the top refugee-receiving schools include 72,407 unique student observations or 39,678 unique prior year test scores. ${ }^{*} p<$ $0.10,{ }^{* *} p<0.05,{ }^{* * *} p<0.01$. 
Table 8

Within-Cohort Refugee Concentration and Existing Student Performance Index Based on Test Scores and Misbehavior, Top Refugee Receiving Schools, Subgroup Analysis, OLS Results

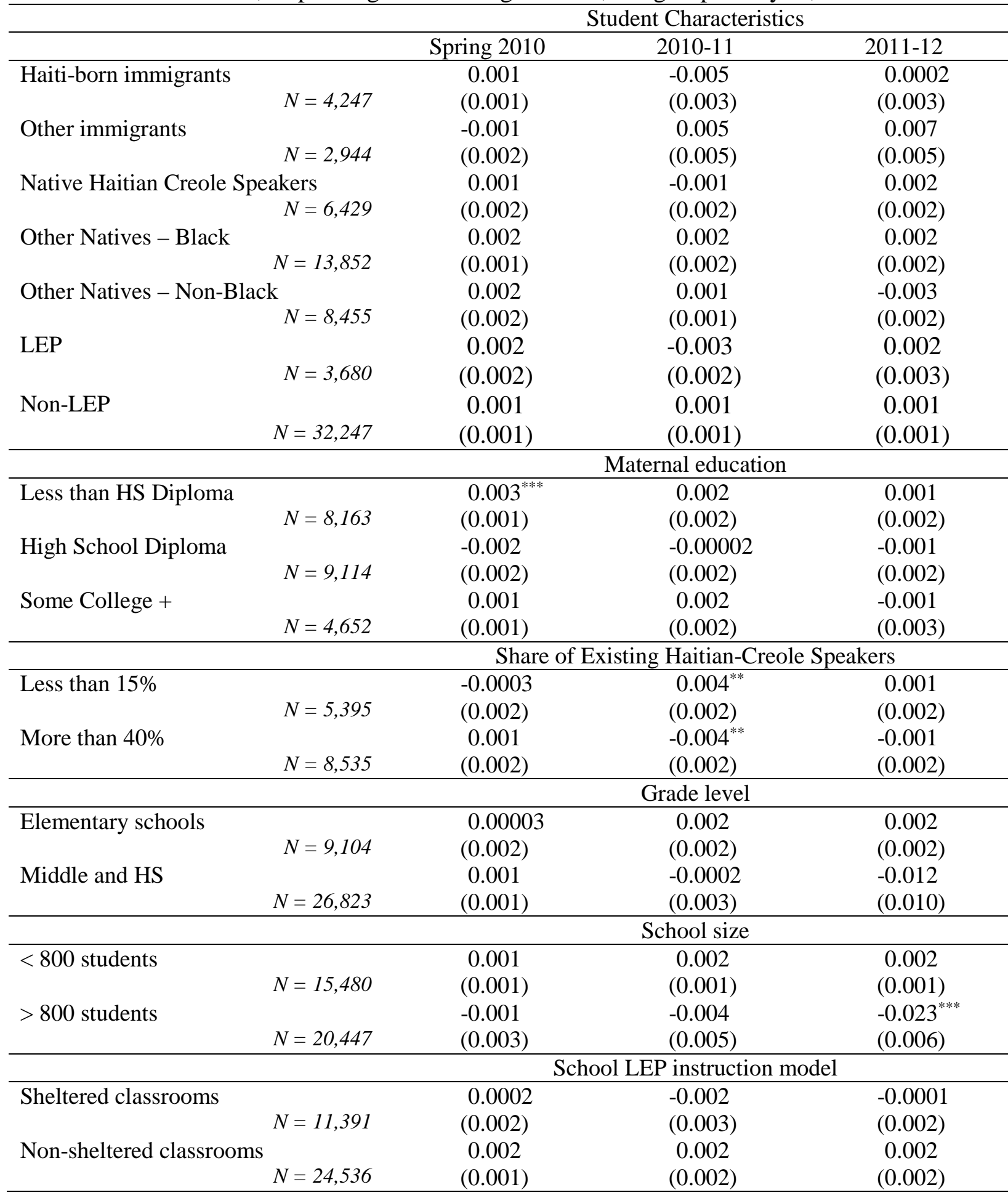

Notes: Robust standard errors clustered at the school level are given in parentheses. Each column represents the effect of within-cohort refugee concentration in Spring 2010 on the outcomes of incumbent students in Spring 2010, 2010-11 and 2011-12, estimated using OLS, by existing student characteristics, maternal education, share of existing Haitian Creole speakers, grade level, school size, and school LEP instruction model. The number of observations 
given represent the number of observations used in the Spring 2010 regressions for the corresponding subgroup. All regressions include school fixed effects and the student characteristics (other than maternal attributes) listed in Table 4. $* \mathrm{p}<0.10, * * \mathrm{p}<0.05, * * * \mathrm{p}<0.01$. 
Table 9

Within-Cohort Refugee Concentration and Existing Student Mobility in Top Refugee Receiving Schools, Subgroup Analysis, OLS Results

\begin{tabular}{|c|c|c|c|c|}
\hline & \multicolumn{4}{|c|}{ Student Characteristics } \\
\hline & \multicolumn{2}{|c|}{ Moved to another public school } & \multicolumn{2}{|c|}{ Left FL public schools } \\
\hline & By Fall 2010 & By Fall 2011 & By Fall 2010 & By Fall 2011 \\
\hline Haiti-born immigrants & 0.003 & -0.001 & 0.004 & $-0.013^{* *}$ \\
\hline$N=4,247$ & $(0.005)$ & $(0.003)$ & $(0.003)$ & $(0.005)$ \\
\hline \multirow[t]{2}{*}{ Other immigrants } & -0.005 & $0.014^{* *}$ & $-0.009^{* *}$ & $-0.017^{* * *}$ \\
\hline & $(0.005)$ & $(0.006)$ & $(0.004)$ & $(0.006)$ \\
\hline Native Haitian Creole Speakers & 0.006 & -0.003 & 0.001 & 0.003 \\
\hline$N=6,429$ & $(0.010)$ & $(0.006)$ & $(0.002)$ & $(0.003)$ \\
\hline Other Natives - Black & 0.003 & 0.002 & -0.002 & -0.003 \\
\hline$N=13,852$ & $(0.006)$ & $(0.004)$ & $(0.002)$ & $(0.002)$ \\
\hline Other Natives - Non-Black & 0.001 & -0.002 & -0.001 & $-0.004^{*}$ \\
\hline \multirow[t]{2}{*}{$N=8,455$} & $(0.006)$ & $(0.006)$ & $(0.002)$ & $(0.002)$ \\
\hline & 0.002 & 0.005 & $0.004^{* *}$ & $-0.010^{* * * *}$ \\
\hline$N=3,680$ & $(0.004)$ & $(0.006)$ & $(0.002)$ & $(0.003)$ \\
\hline \multirow[t]{3}{*}{ Non-LEP } & 0.002 & -0.001 & $-0.003^{*}$ & -0.003 \\
\hline & $(0.006)$ & $(0.004)$ & $(0.001)$ & $(0.002)$ \\
\hline & \multicolumn{4}{|c|}{ Maternal Education } \\
\hline Less than HS Diploma & -0.006 & $-0.013^{* *}$ & -0.0003 & 0.001 \\
\hline$N=8,163$ & $(0.007)$ & $(0.005)$ & $(0.002)$ & $(0.004)$ \\
\hline High School Diploma & 0.001 & 0.0003 & 0.0001 & -0.0002 \\
\hline$N=9,114$ & $(0.007)$ & $(0.004)$ & $(0.002)$ & $(0.003)$ \\
\hline \multirow[t]{3}{*}{ Some College + } & 0.008 & 0.002 & 0.0001 & -0.0003 \\
\hline & $(0.009)$ & $(0.005)$ & $(0.002)$ & $(0.005)$ \\
\hline & Sha & of Existing Haiti & -Creole Speake & \\
\hline Less than $15 \%$ & 0.002 & 0.005 & -0.001 & $-0.010^{* * *}$ \\
\hline$N=5,395$ & $(0.008)$ & $(0.004)$ & $(0.003)$ & $(0.003)$ \\
\hline \multirow{3}{*}{ More than $40 \%$} & 0.010 & 0.007 & 0.001 & -0.007 \\
\hline & $(0.011)$ & $(0.005)$ & $(0.001)$ & $(0.006)$ \\
\hline & & Grade l & & \\
\hline Elementary schools & 0.007 & -0.004 & 0.001 & -0.0004 \\
\hline \multirow{4}{*}{ Middle and HS } & $(0.009)$ & $(0.007)$ & $(0.001)$ & $(0.002)$ \\
\hline & -0.005 & 0.0003 & -0.002 & $-0.007^{*}$ \\
\hline & $(0.004)$ & $(0.004)$ & $(0.002)$ & $(0.004)$ \\
\hline & & School & & \\
\hline$<800$ students & 0.003 & 0.001 & -0.001 & -0.002 \\
\hline \multirow{4}{*}{ > 800 students } & $(0.004)$ & $(0.004)$ & $(0.001)$ & $(0.001)$ \\
\hline & -0.004 & -0.008 & -0.004 & $-0.009^{* *}$ \\
\hline & $(0.009)$ & $(0.006)$ & $(0.004)$ & $(0.004)$ \\
\hline & & School LEP inst & ction model & \\
\hline Sheltered classrooms & 0.003 & 0.002 & 0.001 & $\begin{array}{l}-0.007 \\
\end{array}$ \\
\hline \multirow{3}{*}{$\begin{array}{l}N=11,391 \\
\text { Non-sheltered classrooms } \\
\qquad N=24,536\end{array}$} & (0.009) & $(0.004)$ & $(0.001)$ & $(0.005)$ \\
\hline & $\begin{array}{l}0.001 \\
(0.005)\end{array}$ & $\begin{array}{l}-0.0004 \\
(0.006)\end{array}$ & $\begin{array}{l}-0.003 \\
(0.002)\end{array}$ & $-0.005^{*}$ \\
\hline & (0.005) & $(0.006)$ & $(0.002)$ & $(0.002)$ \\
\hline
\end{tabular}

Notes: Robust standard errors clustered at the school level are given in parentheses. Each column represents the effect of within-cohort refugee concentration in Spring 2010 on incumbent student mobility by Fall 2010 and Fall 2011, estimated using OLS, by existing student characteristics, maternal education, share of existing Haitian Creole 
speakers, grade level, school size, school LEP instruction model. All regressions include school fixed effects and the student characteristics (other than maternal attributes) listed in Table $4 .{ }^{*} p<0.10,{ }^{* *} p<0.05,{ }^{* * *} p<0.01$. 


\section{Appendix Figures and Tables}

Appendix Figure 1

Cross-Grade Variation in Refugee Concentration in Top Refugee-Receiving Schools

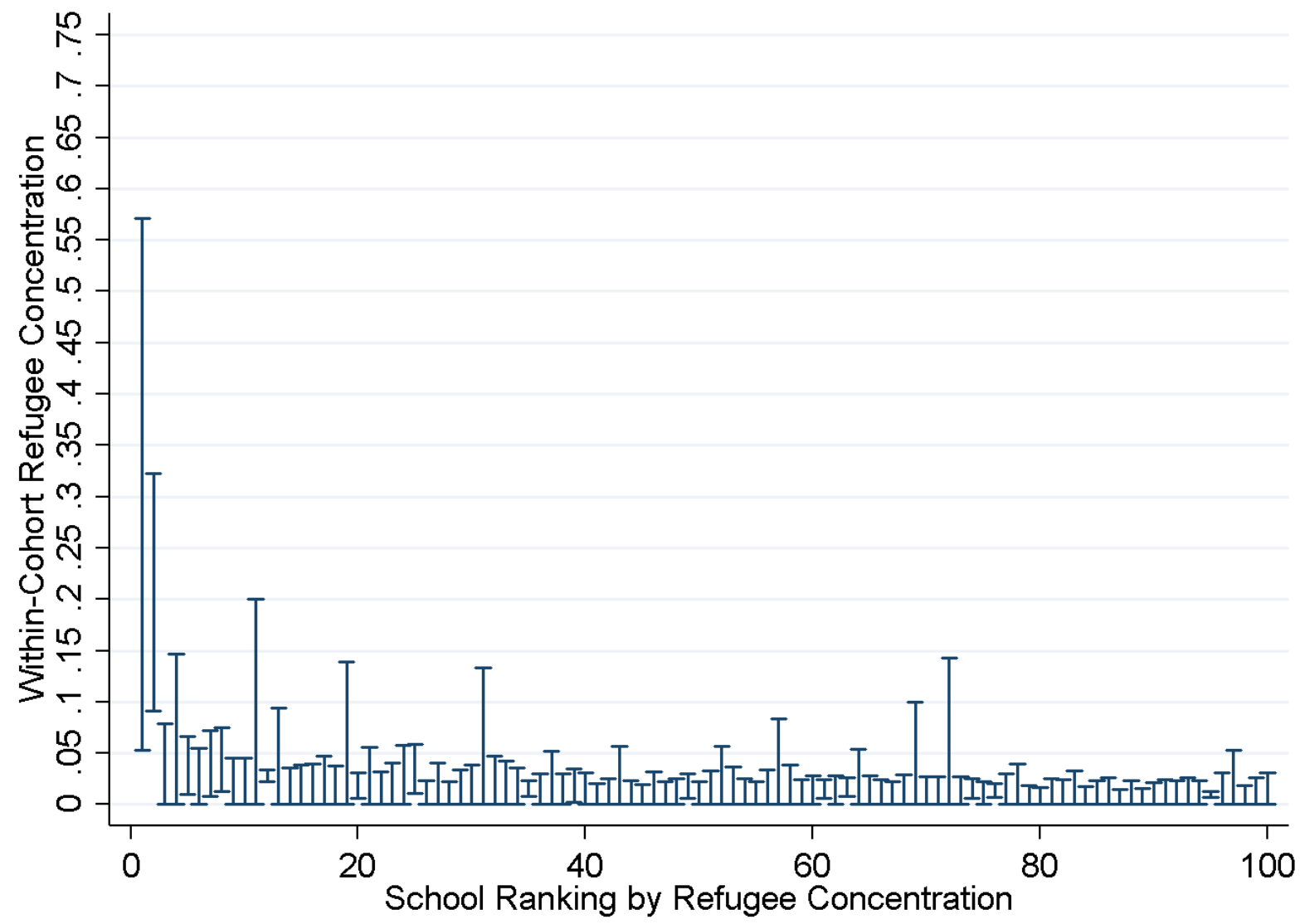

Notes: Capped spikes represent the cross-grade range in refugee concentration. The $\mathrm{x}$-axis ranks the top refugeereceiving schools by refugee concentration. 
Appendix Table 1

Summary Statistics for Outcome Variables Used in the Analysis

\begin{tabular}{|c|c|c|}
\hline & $\begin{array}{l}\text { Refugee-Receiving } \\
\text { Schools }\end{array}$ & $\begin{array}{c}\text { Top Refugee- } \\
\text { Receiving Schools }\end{array}$ \\
\hline $\begin{array}{l}\text { Reading score - Spring } 2010 \\
\qquad N_{1}=560,292, N_{2}=47,918\end{array}$ & $\begin{array}{l}-0.042 \\
(0.996)\end{array}$ & $\begin{array}{l}-0.407 \\
(1.002)\end{array}$ \\
\hline $\begin{array}{l}\text { Reading score - } 1 \text { year later } \\
\qquad N_{1}=425,711, N_{2}=36,680\end{array}$ & $\begin{array}{l}-0.056 \\
(0.979)\end{array}$ & $\begin{array}{l}-0.396 \\
(0.935)\end{array}$ \\
\hline $\begin{array}{l}\text { Reading score - } 2 \text { years later } \\
\qquad N_{1}=338,644, N_{2}=31,099\end{array}$ & $\begin{array}{l}-0.039 \\
(0.960)\end{array}$ & $\begin{array}{l}-0.342 \\
(0.901)\end{array}$ \\
\hline $\begin{array}{l}\text { Math score - Spring } 2010 \\
\qquad N_{1}=539,505, N_{2}=45,441\end{array}$ & $\begin{array}{l}-0.021 \\
(0.998)\end{array}$ & $\begin{array}{l}-0.354 \\
(1.031)\end{array}$ \\
\hline $\begin{array}{l}\text { Math score - } 1 \text { year later } \\
\qquad N_{1}=279,081, N_{2}=25,311\end{array}$ & $\begin{array}{l}-0.028 \\
(0.994)\end{array}$ & $\begin{array}{l}-0.318 \\
(0.956)\end{array}$ \\
\hline $\begin{array}{l}\text { Math score }-2 \text { years later } \\
\qquad N_{1}=203,613, N_{2}=18,919\end{array}$ & $\begin{array}{l}-0.018 \\
(0.990)\end{array}$ & $\begin{array}{l}-0.318 \\
(0.943)\end{array}$ \\
\hline $\begin{array}{l}\text { Disciplinary incident }- \text { Spring } 2010 \\
\qquad N_{1}=864,368, N_{2}=72,317\end{array}$ & $\begin{array}{c}0.142 \\
(0.349)\end{array}$ & $\begin{array}{c}0.161 \\
(0.368)\end{array}$ \\
\hline $\begin{array}{l}\text { Disciplinary incident }-1 \text { year later } \\
\qquad N_{1}=756,355, N_{2}=63,774\end{array}$ & $\begin{array}{c}0.096 \\
(0.295)\end{array}$ & $\begin{array}{c}0.095 \\
(0.293)\end{array}$ \\
\hline $\begin{array}{l}\text { Disciplinary incident }-2 \text { years later } \\
\qquad N_{1}=653,184, N_{2}=56,467\end{array}$ & $\begin{array}{c}0.081 \\
(0.272)\end{array}$ & $\begin{array}{c}0.079 \\
(0.270)\end{array}$ \\
\hline $\begin{array}{l}\text { Performance index - Spring } 2010 \\
\qquad N_{1}=536,199, N_{2}=45,084\end{array}$ & $\begin{array}{l}-0.044 \\
(0.202)\end{array}$ & $\begin{array}{l}-0.111 \\
(0.203)\end{array}$ \\
\hline $\begin{array}{l}\text { Performance index - } 1 \text { year later } \\
\qquad N_{1}=277,205, N_{2}=25,090\end{array}$ & $\begin{array}{l}-0.029 \\
(0.189)\end{array}$ & $\begin{array}{l}-0.0883 \\
(0.183)\end{array}$ \\
\hline $\begin{array}{l}\text { Performance index }-2 \text { years later } \\
\qquad N_{1}=202,093, N_{2}=18,802\end{array}$ & $\begin{array}{l}-0.022 \\
(0.183)\end{array}$ & $\begin{array}{l}-0.0801 \\
(0.176)\end{array}$ \\
\hline $\begin{array}{l}\text { Moved to another school by Fall } 2010 \\
\qquad N_{1}=864,368, N_{2}=72,317\end{array}$ & $\begin{array}{c}0.243 \\
(0.429)\end{array}$ & $\begin{array}{c}0.298 \\
(0.457)\end{array}$ \\
\hline $\begin{array}{l}\text { Moved to another school by Fall } 2011 \\
\qquad N_{1}=864,368, N_{2}=72,317\end{array}$ & $\begin{array}{c}0.374 \\
(0.484)\end{array}$ & $\begin{array}{c}0.438 \\
(0.496)\end{array}$ \\
\hline $\begin{array}{l}\text { Left school system by Fall } 2010 \\
\qquad N_{1}=864,368, N_{2}=72,317\end{array}$ & $\begin{array}{c}0.119 \\
(0.324)\end{array}$ & $\begin{array}{c}0.111 \\
(0.314)\end{array}$ \\
\hline $\begin{array}{l}\text { Left school system by Fall } 2010 \\
\qquad N_{1}=864,368, N_{2}=72,317\end{array}$ & $\begin{array}{c}0.250 \\
(0.433)\end{array}$ & $\begin{array}{c}0.226 \\
(0.418)\end{array}$ \\
\hline
\end{tabular}

Notes: Standard deviations in parentheses. $N_{1}$ and $N_{2}$ represent the number of non-missing observations for the corresponding outcome variable for all refugee receiving schools and top refugee-receiving schools respectively. 
Appendix Table 2

Within-School Age Distribution of Refugees and Existing Student Characteristics Controlling for School Fixed Effects

\begin{tabular}{|c|c|c|}
\hline & $\begin{array}{l}\text { All Refugee-Receiving } \\
\text { Schools }\end{array}$ & $\begin{array}{c}\text { Top Refugee-Receiving } \\
\text { Schools }\end{array}$ \\
\hline Haitian Creole speaker & $\begin{array}{l}-0.0002 \\
(0.002)\end{array}$ & $\begin{array}{c}0.001 \\
(0.003)\end{array}$ \\
\hline Born in Haiti & $\begin{array}{c}0.001 \\
(0.001)\end{array}$ & $\begin{array}{c}0.002 \\
(0.002)\end{array}$ \\
\hline Prior year reading score & $\begin{array}{l}-0.003 \\
(0.007)\end{array}$ & $\begin{array}{c}0.004 \\
(0.010)\end{array}$ \\
\hline Prior year math score & $\begin{array}{c}0.002 \\
(0.008)\end{array}$ & $\begin{array}{c}0.003 \\
(0.014)\end{array}$ \\
\hline Prior year disciplinary incident & $\begin{array}{l}-0.001 \\
(0.002)\end{array}$ & $\begin{array}{l}-0.005^{*} \\
(0.002)\end{array}$ \\
\hline FRPL eligible & $\begin{array}{c}0.002 \\
(0.002)\end{array}$ & $\begin{array}{c}0.002 \\
(0.004)\end{array}$ \\
\hline White & $\begin{array}{l}-0.002^{*} \\
(0.001)\end{array}$ & $\begin{array}{l}-0.001 \\
(0.001)\end{array}$ \\
\hline Hispanic & $\begin{array}{c}0.002 \\
(0.001)\end{array}$ & $\begin{array}{l}-0.001 \\
(0.002)\end{array}$ \\
\hline Black & $\begin{array}{l}-0.001 \\
(0.001)\end{array}$ & $\begin{array}{r}0.003^{*} \\
(0.002)\end{array}$ \\
\hline Asian & $\begin{array}{l}0.001^{* *} \\
(0.0004)\end{array}$ & $\begin{array}{c}0.0002 \\
(0.0004)\end{array}$ \\
\hline Foreign born & $\begin{array}{c}0.003^{* *} \\
(0.003)\end{array}$ & $\begin{array}{c}0.002 \\
(0.002)\end{array}$ \\
\hline Limited English proficient & $\begin{array}{r}0.0003 \\
(0.002)\end{array}$ & $\begin{array}{c}0.002 \\
(0.003)\end{array}$ \\
\hline English non-native & $\begin{array}{c}0.002 \\
(0.002)\end{array}$ & $\begin{array}{l}-0.0003 \\
(0.003)\end{array}$ \\
\hline Special education student & $\begin{array}{l}-0.004^{* * *} \\
(0.001)\end{array}$ & $\begin{array}{l}-0.003^{*} \\
(0.001)\end{array}$ \\
\hline Gifted student & $\begin{array}{r}0.0001 \\
(0.001)\end{array}$ & $\begin{array}{l}-0.002 \\
(0.001)\end{array}$ \\
\hline Age (in months) & $\begin{array}{l}-0.009 \\
(0.050)\end{array}$ & $\begin{array}{c}0.007 \\
(0.084)\end{array}$ \\
\hline Mother -less than HS diploma & $\begin{array}{l}-0.0003 \\
(0.002)\end{array}$ & $\begin{array}{l}-0.001 \\
(0.003)\end{array}$ \\
\hline Mother - some college & $\begin{array}{l}-0.003 \\
(0.002)\end{array}$ & $\begin{array}{l}-0.002 \\
(0.003)\end{array}$ \\
\hline Mother married & $\begin{array}{l}-0.002 \\
(0.002)\end{array}$ & $\begin{array}{l}-0.004 \\
(0.003)\end{array}$ \\
\hline & \multicolumn{2}{|c|}{ Average Teacher Characteristics } \\
\hline Average teacher experience & $\begin{array}{l}-0.131^{* *} \\
(0.060)\end{array}$ & $\begin{array}{l}-0.165^{*} \\
(0.090)\end{array}$ \\
\hline
\end{tabular}


\% novice teachers

\% early career teachers

\% mid-career teachers

\% late career teachers

\% teachers with advanced deg.
0.006

(0.005)

0.00002

(0.004)

$-0.004$

(0.003)

$-0.003$

(0.004)

$-0.003$

(0.004)
0.010

(0.007)

$-0.002$

(0.006)

$-0.002$

(0.004)

$-0.005$

$(0.005)$

$-0.001$

(0.005)

Notes: Robust standard errors clustered at the school level are given in parentheses. Each entry represents the estimated correlation between within-school age distribution of Haitian refugees and the corresponding student attribute or teacher attribute. Regressions using all refugee-receiving schools include 865,399 unique student observations, or 473,465 unique prior year test scores, or 438,187 Florida born students for whom maternal characteristics are available, or 4,493 school-by-grade average teacher characteristics. Regressions using the top refugee-receiving schools include 72,407 unique student observations, or 39,678 unique prior year test scores, or 36,309 Florida born students for whom maternal characteristics are available, or 524 school-by-grade average teacher characteristics. Novice teachers are defined as teachers with no prior experience; early career teachers are identified as those with 1-3 years of experience; mid-career teachers are identified as teachers with 4-10 years of experience, and late career teachers are teachers with more than 10 years of experience. ${ }^{*} p<0.10,{ }^{* *} p<0.05$, ${ }^{* * *} p$ $<0.01$. 
Appendix Table 3 - Within-Cohort Refugee Concentration and Existing Student Test Scores and Misbehavior, IV Results

\begin{tabular}{|c|c|c|c|c|}
\hline & \multicolumn{4}{|c|}{ Spring 2010} \\
\hline & \multicolumn{2}{|c|}{ All Refugee-Receiving Schools } & \multicolumn{2}{|c|}{ Top Refugee-Receiving Schools } \\
\hline & (I) & (II) & (I) & (II) \\
\hline School fixed effects & Yes & Yes & Yes & Yes \\
\hline Student characteristics & No & Yes & No & Yes \\
\hline \multirow[t]{3}{*}{ Reading score } & 0.005 & 0.005 & 0.011 & 0.007 \\
\hline & $(0.007)$ & $(0.005)$ & $(0.010)$ & $(0.007)$ \\
\hline & [404.99] & [432.45] & [128.72] & [151.06] \\
\hline \multirow[t]{3}{*}{ Math score } & -0.002 & -0.003 & 0.006 & 0.004 \\
\hline & $(0.007)$ & $(0.006)$ & $(0.010)$ & $(0.008)$ \\
\hline & [389.37] & {$[408.87]$} & [135.34] & [147.99] \\
\hline \multirow[t]{3}{*}{ Disciplinary incident } & -0.0002 & -0.002 & $-0.005^{*}$ & -0.006 \\
\hline & $(0.002)$ & $(0.003)$ & $(0.003)$ & $(0.004)$ \\
\hline & [1219.80] & [424.04] & [339.86] & [145.10] \\
\hline \multirow[t]{4}{*}{ Performance index } & 0.001 & 0.001 & 0.003 & 0.002 \\
\hline & $(0.001)$ & $(0.001)$ & $(0.002)$ & $(0.002)$ \\
\hline & [415.30] & [415.19] & [153.14] & [153.27] \\
\hline & \multicolumn{4}{|c|}{$2010-11$} \\
\hline Reading score & $0.014^{* *}$ & $0.013^{* * *}$ & $0.018^{* *}$ & $0.014^{*}$ \\
\hline & $(0.006)$ & $(0.005)$ & $(0.007)$ & $(0.007)$ \\
\hline & {$[674.50]$} & [664.70] & [202.50] & [198.53] \\
\hline Math score & 0.011 & 0.007 & 0.013 & 0.005 \\
\hline & $(0.008)$ & $(0.008)$ & $(0.011)$ & $(0.012)$ \\
\hline & [669.07] & [657.00] & [160.63] & [153.82] \\
\hline Disciplinary incident & -0.001 & -0.001 & -0.003 & -0.001 \\
\hline & $(0.001)$ & $(0.002)$ & $(0.002)$ & $(0.002)$ \\
\hline & [1256.47] & [453.10] & [359.47] & [162.74] \\
\hline \multirow[t]{4}{*}{ Performance index } & $0.003^{* *}$ & 0.002 & $0.004^{*}$ & 0.002 \\
\hline & $(0.001)$ & $(0.001)$ & $(0.002)$ & $(0.002)$ \\
\hline & [653.98] & [653.50] & [153.29] & [153.59] \\
\hline & \multicolumn{4}{|c|}{$2011-12$} \\
\hline Reading score & 0.006 & 0.006 & $0.014^{* *}$ & $0.012^{*}$ \\
\hline & $(0.006)$ & $(0.005)$ & $(0.007)$ & $(0.007)$ \\
\hline & [848.93] & {$[839.76]$} & [228.69] & {$[222.50]$} \\
\hline Math score & 0.012 & 0.007 & 0.014 & 0.010 \\
\hline
\end{tabular}




\begin{tabular}{|c|c|c|c|c|}
\hline & $\begin{array}{r}(0.008) \\
{[503.72]}\end{array}$ & $\begin{array}{r}(0.008) \\
{[497.66]}\end{array}$ & $\begin{array}{c}(0.012) \\
{[127.40]}\end{array}$ & $\begin{array}{r}(0.012) \\
{[123.60]}\end{array}$ \\
\hline Disciplinary incident & $\begin{array}{r}-0.002^{*} \\
(0.001) \\
{[1396.20]}\end{array}$ & $\begin{array}{c}-0.003 \\
(0.002) \\
{[491.19]}\end{array}$ & $\begin{array}{c}-0.004^{* *} \\
(0.002) \\
{[447.68]}\end{array}$ & $\begin{array}{c}-0.004 \\
(0.003) \\
{[188.27]}\end{array}$ \\
\hline Performance index & $\begin{array}{c}0.003^{* *} \\
(0.001) \\
{[499.18]}\end{array}$ & $\begin{array}{c}0.002 \\
(0.001) \\
{[498.71]}\end{array}$ & $\begin{array}{c}0.004^{*} \\
(0.002) \\
{[124.09]}\end{array}$ & $\begin{array}{c}0.002 \\
(0.002) \\
{[124.27]}\end{array}$ \\
\hline
\end{tabular}

Notes: Robust standard errors clustered at the school level are given in parentheses. Each column represents the effect of within-cohort refugee concentration in Spring 2010 on the test scores and disciplinary incidents of incumbent students in Spring 2010, 2010-11, and 2011-12, estimated using OLS. Regressions using all refugee-receiving schools include 773,670 unique student observations or 441,221 unique test scores; regressions using the top refugee-receiving schools include 72,407 unique student observations and 39,678 unique test score observations in Spring 2010. Regressions using all refugee-receiving schools include 865,399 unique student observations and 426,028 unique test scores in 2010-11; and 825,376 unique student observations and 338,898 unique test scores in 2011-12. Regressions using all refugee-receiving schools include 72,407 unique student observations and 36,698 unique test scores in 2010-11; and 66,594 unique student observations and 31,114 unique test scores in 2011-12. Columns labeled as (II) introduce the student characteristics (other than maternal attributes) listed in Table 4. First-stage F-stats are given in brackets. ${ }^{*} p<0.10,{ }^{* *} p<0.05,{ }^{* * *} p<0.01$. 
Appendix Table 4

Within-Cohort Refugee Concentration and Student Performance Index in Spring 2010, Conditional on Student Staying in the Sample in the Following Two Years, OLS Results, Controls for School Fixed Effects and Student Characteristics

\begin{tabular}{|c|c|c|c|c|c|c|}
\hline & \multicolumn{3}{|c|}{ All Refugee-Receiving Schools } & \multicolumn{3}{|c|}{ Top Refugee-Receiving Schools } \\
\hline & All students & $\begin{array}{c}\text { In sample in } \\
2010-11\end{array}$ & $\begin{array}{c}\text { In sample in } \\
2011-12\end{array}$ & All students & $\begin{array}{c}\text { In sample in } \\
2010-11\end{array}$ & $\begin{array}{c}\text { In sample in } \\
2011-12\end{array}$ \\
\hline Reading score & $\begin{array}{c}0.002 \\
(0.003) \\
{[455,707]}\end{array}$ & $\begin{array}{c}0.0001 \\
(0.004) \\
{[343,685]}\end{array}$ & $\begin{array}{c}-0.0003 \\
(0.004) \\
{[268,745]}\end{array}$ & $\begin{array}{c}0.006^{*} \\
(0.004) \\
{[37,877]}\end{array}$ & $\begin{array}{c}0.005 \\
(0.005) \\
{[28,922]}\end{array}$ & $\begin{array}{c}0.004 \\
(0.005) \\
{[24,220]}\end{array}$ \\
\hline Math score & $\begin{array}{c}0.001 \\
(0.004) \\
{[440,745]}\end{array}$ & $\begin{array}{l}-0.002 \\
(0.005) \\
{[210,971]}\end{array}$ & $\begin{array}{l}-0.002 \\
(0.006) \\
{[144,378]}\end{array}$ & $\begin{array}{c}0.003 \\
(0.005) \\
{[36,192]}\end{array}$ & $\begin{array}{l}-0.007 \\
(0.007) \\
{[18,822]}\end{array}$ & $\begin{array}{l}-0.007 \\
(0.009) \\
{[13,319]}\end{array}$ \\
\hline Disciplinary incident & $\begin{array}{c}0.001 \\
(0.002) \\
{[458,177]}\end{array}$ & $\begin{array}{c}0.001 \\
(0.002) \\
{[443,470]}\end{array}$ & $\begin{array}{c}0.001 \\
(0.002) \\
{[403,307]}\end{array}$ & $\begin{array}{l}-0.002 \\
(0.002) \\
{[38,142]}\end{array}$ & $\begin{array}{l}-0.002 \\
(0.003) \\
{[36,676]}\end{array}$ & $\begin{array}{l}-0.001 \\
(0.003) \\
{[33,003]}\end{array}$ \\
\hline Performance index & $\begin{array}{c}-0.0001 \\
(0.001) \\
{[438,275]}\end{array}$ & $\begin{array}{c}-0.0004 \\
(0.001) \\
{[210,217]}\end{array}$ & $\begin{array}{c}0.0001 \\
(0.001) \\
{[143,564]}\end{array}$ & $\begin{array}{c}0.001 \\
(0.001) \\
{[35,927]}\end{array}$ & $\begin{array}{l}-0.001 \\
(0.001) \\
{[18,730]}\end{array}$ & $\begin{array}{c}-0.0001 \\
(0.001) \\
{[13,224]}\end{array}$ \\
\hline
\end{tabular}

Notes: Robust standard errors clustered at the school level are given in parentheses. Each column represents the effect of within-cohort refugee concentration in Spring 2010 on the outcomes of incumbent students in Spring 2010 using all students, using students observed in 2010-11, and using students observed in 201112. All regressions include school and grade fixed effects and the student characteristics (other than the maternal attributes) listed in Table 4 . Number of observations used in each regression is given in brackets. ${ }^{*} p<0.10,{ }^{* *} p<0.05,{ }^{* * *} p<0.01$. 
Appendix Table 5

Within-Cohort Refugee Concentration and Existing Student Mobility, IV Results

\begin{tabular}{|c|c|c|}
\hline & \multicolumn{2}{|c|}{ By Fall $2010 \ldots$} \\
\hline & \multicolumn{2}{|c|}{ All Refugee-Receiving Schools } \\
\hline & (I) & (II) \\
\hline School fixed effects & Yes & Yes \\
\hline Student characteristics & No & Yes \\
\hline \multirow[t]{2}{*}{ Moved to another public school } & 0.004 & 0.005 \\
\hline & $(0.004)$ & $(0.008)$ \\
\hline \multirow[t]{2}{*}{ Left FL public schools } & 0.0001 & -0.002 \\
\hline & $(0.001)$ & $(0.001)$ \\
\hline \multirow[t]{2}{*}{ First-stage F-stat } & 1131.24 & 387.27 \\
\hline & \multicolumn{2}{|c|}{ Top Refugee-Receiving Schools } \\
\hline \multirow[t]{2}{*}{ Moved to another public school } & -0.0002 & 0.00004 \\
\hline & $(0.005)$ & $(0.011)$ \\
\hline \multirow[t]{2}{*}{ Left FL public schools } & 0.002 & 0.005 \\
\hline & $(0.005)$ & $(0.010)$ \\
\hline \multirow[t]{3}{*}{ First-stage F-stat } & 325.22 & 139.75 \\
\hline & \multicolumn{2}{|c|}{ By Fall $2011 \ldots$} \\
\hline & \multicolumn{2}{|c|}{ All Refugee-Receiving Schools } \\
\hline \multirow[t]{2}{*}{ Moved to another public school } & 0.004 & -0.003 \\
\hline & $(0.003)$ & $(0.004)$ \\
\hline \multirow[t]{2}{*}{ Left FL public schools } & 0.001 & 0.0004 \\
\hline & $(0.002)$ & $(0.002)$ \\
\hline \multirow[t]{2}{*}{ First-stage F-stat } & 1131.24 & 387.27 \\
\hline & \multicolumn{2}{|c|}{ Top Refugee-Receiving Schools } \\
\hline Moved to another public school & $\begin{array}{l}-0.002 \\
(0.002)\end{array}$ & $\begin{array}{l}-0.005^{* * *} \\
(0.002)\end{array}$ \\
\hline Left FL public schools & 0.001 & -0.005 \\
\hline & $(0.005)$ & $(0.007)$ \\
\hline First-stage F-stat & 325.22 & 139.75 \\
\hline
\end{tabular}

Notes: Robust standard errors clustered at the school level are given in parentheses. Each column represents the effect of within-cohort refugee concentration in Spring 2010 on the mobility of incumbent students by Fall 2010, and by Fall 2011 estimated using IV. Regressions using all refugee-receiving schools include 772,467 unique student observations. Regressions using the top refugee-receiving schools include 72,407 unique student observations. Columns labeled as (II) introduce the student characteristics (other than maternal attributes) listed in Table 4. First-stage F-stats are given in brackets. ${ }^{*} p<0.10,{ }^{* *} p<0.05,{ }^{* * *} p<0.01$. 
Appendix Table 6

Within-Cohort Refugee Concentration and Existing Student Characteristics, by Existing Student Characteristics in Top Refugee-

Receiving Schools

\begin{tabular}{|c|c|c|c|c|c|c|c|}
\hline & $\begin{array}{c}\text { Haiti-Born } \\
\text { Immigrants } \\
N=4,247\end{array}$ & $\begin{array}{c}\text { Other } \\
\text { Immigrants } \\
N=2,944\end{array}$ & $\begin{array}{l}\text { Native } \\
\text { Haitian- } \\
\text { Creole } \\
\text { Speakers } \\
N=6,429\end{array}$ & $\begin{array}{c}\text { Other Native } \\
\text { Students - } \\
\text { Black } \\
N=13,852\end{array}$ & $\begin{array}{c}\text { Other Native } \\
\text { Students Non- } \\
\text { Black } \\
\quad N=8,455\end{array}$ & $\begin{array}{c}\text { LEP } \\
\text { Students } \\
N=3,680\end{array}$ & $\begin{array}{c}\text { Non-LEP } \\
\text { Students } \\
N=32,247\end{array}$ \\
\hline Haitian Creole speaker & $\begin{array}{l}-0.002 \\
(0.002)\end{array}$ & $\begin{array}{c}0.001 \\
(0.002)\end{array}$ & & & & $\begin{array}{l}-0.001 \\
(0.003)\end{array}$ & $\begin{array}{c}0.001 \\
(0.002)\end{array}$ \\
\hline Prior year reading score & $\begin{array}{l}-0.028^{* * *} \\
(0.008)\end{array}$ & $\begin{array}{l}-0.012 \\
(0.018)\end{array}$ & $\begin{array}{c}0.005 \\
(0.010)\end{array}$ & $\begin{array}{l}-0.007 \\
(0.006)\end{array}$ & $\begin{array}{c}0.005 \\
(0.011)\end{array}$ & $\begin{array}{l}-0.016^{*} \\
(0.009)\end{array}$ & $\begin{array}{l}-0.001 \\
(0.007)\end{array}$ \\
\hline Prior year math score & $\begin{array}{l}-0.004 \\
(0.011)\end{array}$ & $\begin{array}{l}-0.019 \\
(0.023)\end{array}$ & $\begin{array}{c}0.011 \\
(0.011)\end{array}$ & $\begin{array}{l}-0.011 \\
(0.008)\end{array}$ & $\begin{array}{l}-0.001 \\
(0.014)\end{array}$ & $\begin{array}{l}-0.003 \\
(0.011)\end{array}$ & $\begin{array}{l}-0.002 \\
(0.009)\end{array}$ \\
\hline Prior year disciplinary incident & $\begin{array}{l}-0.002 \\
(0.002)\end{array}$ & $\begin{array}{l}-0.004 \\
(0.003)\end{array}$ & $\begin{array}{l}-0.002 \\
(0.003)\end{array}$ & $\begin{array}{l}-0.003 \\
(0.002)\end{array}$ & $\begin{array}{l}-0.003^{*} \\
(0.001)\end{array}$ & $\begin{array}{l}-0.004^{*} \\
(0.002)\end{array}$ & $\begin{array}{l}-0.002 \\
(0.002)\end{array}$ \\
\hline FRPL eligible & $\begin{array}{l}-0.003 \\
(0.002)\end{array}$ & $\begin{array}{l}-0.003 \\
(0.004)\end{array}$ & $\begin{array}{c}0.002 \\
(0.003)\end{array}$ & $\begin{array}{c}0.002 \\
(0.003)\end{array}$ & $\begin{array}{l}-0.002 \\
(0.003)\end{array}$ & $\begin{array}{l}-0.004 \\
(0.002)\end{array}$ & $\begin{array}{l}-0.0001 \\
(0.002)\end{array}$ \\
\hline White & $\begin{array}{l}-0.0001 \\
(0.0001)\end{array}$ & $\begin{array}{l}-0.002 \\
(0.002)\end{array}$ & $\begin{array}{c}0.0002 \\
(0.0002)\end{array}$ & & $\begin{array}{c}0.001 \\
(0.002)\end{array}$ & $\begin{array}{c}0.0004 \\
(0.001)\end{array}$ & $\begin{array}{l}-0.0002 \\
(0.0008)\end{array}$ \\
\hline Hispanic & $\begin{array}{l}-0.001 \\
(0.0003)\end{array}$ & $\begin{array}{c}0.006 \\
(0.005)\end{array}$ & $\begin{array}{l}-0.0006 \\
(0.0007)\end{array}$ & & $\begin{array}{c}0.0004 \\
(0.002)\end{array}$ & $\begin{array}{l}-0.001 \\
(0.002)\end{array}$ & $\begin{array}{l}-0.001 \\
(0.001)\end{array}$ \\
\hline Black & $\begin{array}{c}0.0003 \\
(0.0005)\end{array}$ & $\begin{array}{l}-0.002 \\
(0.005)\end{array}$ & $\begin{array}{c}0.0008 \\
(0.001)\end{array}$ & & & $\begin{array}{c}0.0006 \\
(0.002)\end{array}$ & $\begin{array}{c}0.002 \\
(0.001)\end{array}$ \\
\hline Asian & $\begin{array}{c}0.0002 \\
(0.0002)\end{array}$ & $\begin{array}{l}-0.002 \\
(0.002)\end{array}$ & $\begin{array}{c}0.0001 \\
(0.0002)\end{array}$ & & $\begin{array}{c}0.0002 \\
(0.001)\end{array}$ & $\begin{array}{c}0.001 \\
(0.001)\end{array}$ & $\begin{array}{l}-0.0002 \\
(0.0003)\end{array}$ \\
\hline Limited English proficient & $\begin{array}{c}0.003 \\
(0.002)\end{array}$ & $\begin{array}{c}0.011^{* *} \\
(0.004)\end{array}$ & $\begin{array}{l}-0.003 \\
(0.004)\end{array}$ & $\begin{array}{l}-0.0001 \\
(0.001)\end{array}$ & $\begin{array}{l}-0.004^{*} \\
(0.002)\end{array}$ & & \\
\hline English non-native & $\begin{array}{l}-0.001 \\
(0.001)\end{array}$ & $\begin{array}{c}0.001 \\
(0.004)\end{array}$ & & $\begin{array}{l}-0.001 \\
(0.001)\end{array}$ & $\begin{array}{c}0.001 \\
(0.002)\end{array}$ & $\begin{array}{l}-0.001 \\
(0.001)\end{array}$ & $\begin{array}{c}0.0001 \\
(0.002)\end{array}$ \\
\hline Special education student & $\begin{array}{c}0.002 \\
(0.001)\end{array}$ & $\begin{array}{c}0.001 \\
(0.002)\end{array}$ & $\begin{array}{l}-0.001 \\
(0.003)\end{array}$ & $\begin{array}{l}-0.001 \\
(0.001)\end{array}$ & $\begin{array}{l}-0.003^{*} \\
(0.002)\end{array}$ & $\begin{array}{l}-0.001 \\
(0.001)\end{array}$ & $\begin{array}{l}-0.001 \\
(0.001)\end{array}$ \\
\hline Gifted student & $\begin{array}{l}-0.0004 \\
(0.001)\end{array}$ & $\begin{array}{c}0.002 \\
(0.001)\end{array}$ & $\begin{array}{c}0.002 \\
(0.002)\end{array}$ & $\begin{array}{l}-0.001 \\
(0.001)\end{array}$ & $\begin{array}{l}-0.002 \\
(0.001)\end{array}$ & $\begin{array}{l}-0.000003 \\
(0.001)\end{array}$ & $\begin{array}{l}-0.001 \\
(0.001)\end{array}$ \\
\hline Age (in months) & $\begin{array}{l}-0.078 \\
(0.104)\end{array}$ & $\begin{array}{c}0.246^{*} \\
(0.127)\end{array}$ & $\begin{array}{l}0.271^{* * *} \\
(0.085)\end{array}$ & $\begin{array}{c}0.063 \\
(0.083)\end{array}$ & $\begin{array}{c}0.031 \\
(0.082)\end{array}$ & $\begin{array}{l}-0.003 \\
(0.111)\end{array}$ & $\begin{array}{c}0.057 \\
(0.094)\end{array}$ \\
\hline
\end{tabular}


Mother -less than HS diploma

Mother - some college

Mother married

Notes: Robust standard errors clustered at the school level are given in parentheses. Each entry represents

refugee concentration and the corresponding student attribute with school fixed effects, by existing student characteristics. Number of observations presented at the bottom of each column heading provides the number of unique students in each subgroup. ${ }^{*} p<0.10,{ }^{* *} p<0.05,{ }^{* * *} p<0.01$. 
Appendix Table 7

Within-Cohort Refugee Concentration and Existing Student Characteristics, by Maternal Education Level of Existing Students in Top Refugee-Receiving Schools

\begin{tabular}{|c|c|c|c|}
\hline & $\begin{array}{l}\text { Less than HS Diploma } \\
\qquad N=8,163 \\
\end{array}$ & $\begin{array}{l}\text { HS Diploma } \\
N=9,114\end{array}$ & $\begin{array}{c}\text { Some College or Higher } \\
\qquad N=4,652\end{array}$ \\
\hline \multirow[t]{2}{*}{ Haitian Creole speaker } & -0.001 & -0.001 & -0.0001 \\
\hline & $(0.003)$ & $(0.003)$ & $(0.002)$ \\
\hline \multirow[t]{2}{*}{ Haiti born } & 0.001 & -0.0001 & 0.0002 \\
\hline & $(0.0004)$ & $(0.0001)$ & $(0.0002)$ \\
\hline \multirow[t]{2}{*}{ Prior year reading score } & 0.009 & -0.009 & -0.001 \\
\hline & $(0.010)$ & $(0.008)$ & $(0.013)$ \\
\hline \multirow{2}{*}{ Prior year math score } & 0.016 & 0.004 & -0.020 \\
\hline & $(0.012)$ & $(0.009)$ & $(0.014)$ \\
\hline \multirow[t]{2}{*}{ Prior year disciplinary incident } & $-0.009^{* * *}$ & -0.002 & -0.002 \\
\hline & $(0.003)$ & $(0.002)$ & $(0.002)$ \\
\hline \multirow{2}{*}{ FRPL eligible } & 0.001 & -0.002 & 0.001 \\
\hline & $(0.003)$ & $(0.002)$ & $(0.003)$ \\
\hline \multirow{2}{*}{ White } & 0.002 & 0.001 & $-0.005^{* *}$ \\
\hline & $(0.001)$ & $(0.001)$ & $(0.002)$ \\
\hline \multirow[t]{2}{*}{ Hispanic } & -0.0002 & 0.002 & -0.003 \\
\hline & $(0.002)$ & $(0.003)$ & $(0.003)$ \\
\hline \multirow[t]{2}{*}{ Black } & -0.002 & -0.001 & $0.008^{* *}$ \\
\hline & $(0.003)$ & $(0.003)$ & $(0.004)$ \\
\hline \multirow[t]{2}{*}{ Asian } & 0.0003 & -0.001 & 0.001 \\
\hline & $(0.0003)$ & $(0.001)$ & $(0.001)$ \\
\hline \multirow[t]{2}{*}{ Foreign born } & 0.001 & 0.0002 & 0.0003 \\
\hline & $(0.0004)$ & $(0.0004)$ & $(0.0003)$ \\
\hline \multirow[t]{2}{*}{ Limited English proficient } & -0.0003 & -0.002 & -0.002 \\
\hline & $(0.003)$ & $(0.003)$ & $(0.003)$ \\
\hline \multirow[t]{2}{*}{ English non-native } & 0.001 & -0.003 & -0.001 \\
\hline & $(0.004)$ & $(0.004)$ & $(0.004)$ \\
\hline \multirow[t]{2}{*}{ Special education student } & 0.003 & $0.003^{*}$ & -0.001 \\
\hline & $(0.003)$ & $(0.002)$ & $(0.003)$ \\
\hline \multirow[t]{2}{*}{ Gifted student } & -0.001 & -0.001 & -0.002 \\
\hline & $(0.002)$ & $(0.002)$ & $(0.002)$ \\
\hline Age (in months) & 0.036 & $0.153^{* *}$ & 0.057 \\
\hline
\end{tabular}


Notes: Robust standard errors clustered at the school level are given in parentheses. Each entry represents the estimated correlation between within-cohort refugee concentration and the corresponding student attribute with school fixed effects, by existing student maternal characteristics. Number of observations presented at the bottom of each column heading provides the number of unique students in each subgroup. ${ }^{*} p<0.10,{ }^{* *} p<0.05,{ }^{* * *} p<0.01$. 
Appendix Table 8

Within-Cohort Refugee Concentration and Existing Student Characteristics, by School Characteristics in Top Refugee-Receiving Schools

\begin{tabular}{|c|c|c|c|c|c|c|c|c|}
\hline & $\begin{array}{c}\text { Elementary } \\
\text { Grades } \\
N=9,104 \\
\end{array}$ & $\begin{array}{l}\text { Middle and } \\
\text { High } \\
\text { School } \\
\text { Grades } \\
N=26,823 \\
\end{array}$ & $\begin{array}{c}\text { HC } \\
\text { Speakers } \\
\text { Less than } \\
15 \text { Percent } \\
N=5,395 \\
\end{array}$ & $\begin{array}{c}\text { HC Speakers } \\
\text { More than } 40 \\
\text { Percent } \\
N=8,535 \\
\end{array}$ & $\begin{array}{c}<800 \\
\text { Students } \\
N=15,480\end{array}$ & $\begin{array}{c}>800 \\
\text { Students } \\
N= \\
20,447 \\
\end{array}$ & $\begin{array}{c}\text { Sheltered } \\
\text { classrooms } \\
N=11,391\end{array}$ & $\begin{array}{c}\text { Non- } \\
\text { sheltered } \\
\text { classrooms } \\
N=24,536 \\
\end{array}$ \\
\hline Haitian Creole speaker & $\begin{array}{c}0.001 \\
(0.003)\end{array}$ & $\begin{array}{l}-0.001 \\
(0.002)\end{array}$ & $\begin{array}{c}0.001 \\
(0.002)\end{array}$ & $\begin{array}{l}-0.0003 \\
(0.003)\end{array}$ & $\begin{array}{l}-0.001 \\
(0.002)\end{array}$ & $\begin{array}{r}0.004 \\
(0.004)\end{array}$ & $\begin{array}{c}0.003 \\
(0.003)\end{array}$ & $\begin{array}{l}-0.002 \\
(0.002)\end{array}$ \\
\hline Born in Haiti & $\begin{array}{c}0.002 \\
(0.001)\end{array}$ & $\begin{array}{c}0.001 \\
(0.002)\end{array}$ & $\begin{array}{c}0.001 \\
(0.001)\end{array}$ & $\begin{array}{c}0.003 \\
(0.002)\end{array}$ & $\begin{array}{c}0.001 \\
(0.002)\end{array}$ & $\begin{array}{r}0.002 \\
(0.003)\end{array}$ & $\begin{array}{c}0.004^{*} \\
(0.002)\end{array}$ & $\begin{array}{c}0.001 \\
(0.001)\end{array}$ \\
\hline Prior year reading score & $\begin{array}{l}-0.003 \\
(0.007)\end{array}$ & $\begin{array}{l}-0.007 \\
(0.009)\end{array}$ & $\begin{array}{c}0.018 \\
(0.011)\end{array}$ & $\begin{array}{l}-0.008 \\
(0.012)\end{array}$ & $\begin{array}{c}0.004 \\
(0.007)\end{array}$ & $\begin{array}{c}-0.020 \\
(0.020)\end{array}$ & $\begin{array}{l}-0.012 \\
(0.009)\end{array}$ & $\begin{array}{c}0.003 \\
(0.010)\end{array}$ \\
\hline Prior year math score & $\begin{array}{l}-0.002 \\
(0.010)\end{array}$ & $\begin{array}{l}-0.010 \\
(0.010)\end{array}$ & $\begin{array}{c}0.013 \\
(0.017)\end{array}$ & $\begin{array}{c}0.005 \\
(0.014)\end{array}$ & $\begin{array}{c}0.003 \\
(0.006)\end{array}$ & $\begin{array}{c}-0.021 \\
(0.022)\end{array}$ & $\begin{array}{l}-0.001 \\
(0.011)\end{array}$ & $\begin{array}{l}-0.009 \\
(0.013)\end{array}$ \\
\hline Prior year disciplinary incident & $\begin{array}{l}-0.002 \\
(0.002)\end{array}$ & $\begin{array}{l}-0.003 \\
(0.002)\end{array}$ & $\begin{array}{l}-0.001 \\
(0.003)\end{array}$ & $\begin{array}{l}-0.001 \\
(0.002)\end{array}$ & $\begin{array}{l}-0.002 \\
(0.001)\end{array}$ & $\begin{array}{c}-0.006 \\
(0.005)\end{array}$ & $\begin{array}{l}-0.002 \\
(0.001)\end{array}$ & $\begin{array}{l}-0.004^{*} \\
(0.002)\end{array}$ \\
\hline FRPL eligible & $\begin{array}{c}0.002 \\
(0.002)\end{array}$ & $\begin{array}{l}-0.003 \\
(0.003)\end{array}$ & $\begin{array}{c}0.011 \\
(0.010)\end{array}$ & $\begin{array}{l}-0.002 \\
(0.002)\end{array}$ & $\begin{array}{l}-0.001 \\
(0.002)\end{array}$ & $\begin{array}{c}-0.005 \\
(0.010)\end{array}$ & $\begin{array}{l}-0.002 \\
(0.002)\end{array}$ & $\begin{array}{c}0.002 \\
(0.003)\end{array}$ \\
\hline White & $\begin{array}{l}-0.0004 \\
(0.001)\end{array}$ & $\begin{array}{c}0.0002 \\
(0.001)\end{array}$ & $\begin{array}{l}-0.001 \\
(0.001)\end{array}$ & $\begin{array}{l}-0.001 \\
(0.001)\end{array}$ & $\begin{array}{c}0.0004 \\
(0.001)\end{array}$ & $\begin{array}{r}0.001 \\
(0.002)\end{array}$ & $\begin{array}{l}-0.001 \\
(0.001)\end{array}$ & $\begin{array}{c}0.0004 \\
(0.001)\end{array}$ \\
\hline Hispanic & $\begin{array}{l}-0.002 \\
(0.002)\end{array}$ & $\begin{array}{l}-0.001 \\
(0.002)\end{array}$ & $\begin{array}{c}0.002 \\
(0.002)\end{array}$ & $\begin{array}{l}-0.00004 \\
(0.002)\end{array}$ & $\begin{array}{l}-0.0003 \\
(0.001)\end{array}$ & $\begin{array}{c}-0.006^{* *} \\
(0.003)\end{array}$ & $\begin{array}{l}-0.001 \\
(0.002)\end{array}$ & $\begin{array}{l}-0.001 \\
(0.001)\end{array}$ \\
\hline Black & $\begin{array}{c}0.003 \\
(0.002)\end{array}$ & $\begin{array}{c}0.001 \\
(0.001)\end{array}$ & $\begin{array}{l}-0.001 \\
(0.002)\end{array}$ & $\begin{array}{c}0.001 \\
(0.002)\end{array}$ & $\begin{array}{c}0.0003 \\
(0.001)\end{array}$ & $\begin{array}{l}0.007^{* *} \\
(0.003)\end{array}$ & $\begin{array}{c}0.002 \\
(0.002)\end{array}$ & $\begin{array}{c}0.001 \\
(0.002)\end{array}$ \\
\hline Asian & $\begin{array}{c}0.0002 \\
(0.0004)\end{array}$ & $\begin{array}{l}-0.0001 \\
(0.0003)\end{array}$ & $\begin{array}{c}0.001 \\
(0.001)\end{array}$ & $\begin{array}{l}-0.0001 \\
(0.0002)\end{array}$ & $\begin{array}{c}0.0001 \\
(0.0003)\end{array}$ & $\begin{array}{c}-0.001 \\
(0.001)\end{array}$ & $\begin{array}{l}-0.00001 \\
(0.0004)\end{array}$ & $\begin{array}{l}-0.0002 \\
(0.0003)\end{array}$ \\
\hline Foreign born & $\begin{array}{c}0.002 \\
(0.002)\end{array}$ & $\begin{array}{c}0.001 \\
(0.002)\end{array}$ & $\begin{array}{c}0.001 \\
(0.002)\end{array}$ & $\begin{array}{l}0.004^{* *} \\
(0.002)\end{array}$ & $\begin{array}{c}0.002 \\
(0.002)\end{array}$ & $\begin{array}{c}-0.002 \\
(0.005)\end{array}$ & $\begin{array}{l}0.003^{* *} \\
(0.002)\end{array}$ & $\begin{array}{c}0.001 \\
(0.002)\end{array}$ \\
\hline Limited English proficient & $\begin{array}{l}-0.003 \\
(0.003)\end{array}$ & $\begin{array}{c}0.003 \\
(0.002)\end{array}$ & $\begin{array}{l}-0.001 \\
(0.002)\end{array}$ & $\begin{array}{c}0.005^{* *} \\
(0.002)\end{array}$ & $\begin{array}{l}0.00001 \\
(0.002)\end{array}$ & $\begin{array}{r}0.002 \\
(0.004)\end{array}$ & $\begin{array}{c}0.003 \\
(0.002)\end{array}$ & $\begin{array}{c}0.0004 \\
(0.002)\end{array}$ \\
\hline English non-native & $\begin{array}{l}-0.001 \\
(0.003)\end{array}$ & $\begin{array}{l}-0.001 \\
(0.002)\end{array}$ & $\begin{array}{c}0.003 \\
(0.002)\end{array}$ & $\begin{array}{c}0.0001 \\
(0.003)\end{array}$ & $\begin{array}{l}-0.001 \\
(0.002)\end{array}$ & $\begin{array}{c}-0.005 \\
(0.005)\end{array}$ & $\begin{array}{c}0.002 \\
(0.003)\end{array}$ & $\begin{array}{l}-0.003 \\
(0.002)\end{array}$ \\
\hline Special education student & $\begin{array}{c}0.0002 \\
(0.001)\end{array}$ & $\begin{array}{l}-0.002 \\
(0.001)\end{array}$ & $\begin{array}{l}-0.003^{*} \\
(0.002)\end{array}$ & $\begin{array}{c}0.0003 \\
(0.001)\end{array}$ & $\begin{array}{l}-0.0003 \\
(0.001)\end{array}$ & $\begin{array}{c}-0.004 \\
(0.003)\end{array}$ & $\begin{array}{l}-0.0003 \\
(0.001)\end{array}$ & $\begin{array}{l}-0.002^{*} \\
(0.001)\end{array}$ \\
\hline
\end{tabular}




\begin{tabular}{|c|c|c|c|c|c|c|c|c|}
\hline Gifted student & $\begin{array}{l}-0.003^{* *} \\
(0.001)\end{array}$ & $\begin{array}{c}0.001 \\
(0.001)\end{array}$ & $\begin{array}{l}-0.002 \\
(0.001)\end{array}$ & $\begin{array}{c}0.001 \\
(0.001)\end{array}$ & $\begin{array}{l}-0.001 \\
(0.001)\end{array}$ & $\begin{array}{r}0.0004 \\
(0.002)\end{array}$ & $\begin{array}{c}0.0001 \\
(0.001)\end{array}$ & $\begin{array}{l}-0.001 \\
(0.001)\end{array}$ \\
\hline Age (in months) & $\begin{array}{c}0.099^{* *} \\
(0.037)\end{array}$ & $\begin{array}{c}0.036 \\
(0.113)\end{array}$ & $\begin{array}{c}0.053 \\
(0.122)\end{array}$ & $\begin{array}{c}0.016 \\
(0.084)\end{array}$ & $\begin{array}{c}0.019 \\
(0.058)\end{array}$ & $\begin{array}{r}0.046 \\
(0.085)\end{array}$ & $\begin{array}{c}0.065 \\
(0.092)\end{array}$ & $\begin{array}{c}0.063 \\
(0.111)\end{array}$ \\
\hline Mother -less than HS diploma & $\begin{array}{l}-0.003 \\
(0.003)\end{array}$ & $\begin{array}{c}0.002 \\
(0.003)\end{array}$ & $\begin{array}{l}-0.003 \\
(0.004)\end{array}$ & $\begin{array}{l}-0.003 \\
(0.003)\end{array}$ & $\begin{array}{l}-0.002 \\
(0.002)\end{array}$ & $\begin{array}{c}-0.002 \\
(0.006)\end{array}$ & $\begin{array}{l}-0.001 \\
(0.003)\end{array}$ & $\begin{array}{l}-0.001 \\
(0.002)\end{array}$ \\
\hline Mother - some college & $\begin{array}{l}-0.001 \\
(0.003)\end{array}$ & $\begin{array}{c}0.001 \\
(0.002)\end{array}$ & $\begin{array}{c}0.001 \\
(0.003)\end{array}$ & $\begin{array}{l}0.003^{*} \\
(0.002)\end{array}$ & $\begin{array}{c}0.001 \\
(0.002)\end{array}$ & $\begin{array}{c}-0.004 \\
(0.003)\end{array}$ & $\begin{array}{c}0.003 \\
(0.002)\end{array}$ & $\begin{array}{l}-0.002 \\
(0.002)\end{array}$ \\
\hline Mother married & $\begin{array}{l}-0.002 \\
(0.003)\end{array}$ & $\begin{array}{c}0.001 \\
(0.003)\end{array}$ & $\begin{array}{l}-0.005 \\
(0.004)\end{array}$ & $\begin{array}{c}0.003 \\
(0.005)\end{array}$ & $\begin{array}{l}-0.002 \\
(0.002)\end{array}$ & $\begin{array}{r}0.008 \\
(0.005)\end{array}$ & $\begin{array}{c}0.002 \\
(0.004)\end{array}$ & $\begin{array}{l}-0.001 \\
(0.002)\end{array}$ \\
\hline
\end{tabular}

Notes: Robust standard errors clustered at the school level are given in parentheses. Each entry represents the estimated correlation between within-cohort refugee concentration and the corresponding student attribute with school fixed effects, by the share of existing Haitian-Creole speakers in school and grade level. Number of observations presented at the bottom of each column heading provides the number of unique students in each subgroup. ${ }^{*} p<0.10,{ }^{* *} p<0.05$, ${ }^{* * *} p<0.01$. 
Appendix Table 9

Within-Cohort Refugee Concentration and Incumbent Student Test Scores and Misbehavior in Top Refugee-Receiving Schools, Pseudo Effects, OLS Estimates, Controls for School Fixed Effects

\begin{tabular}{lcc}
\hline & $2007-08$ & $2008-09$ \\
\hline Reading score & -0.0003 & -0.006 \\
& $(0.001)$ & $(0.004)$ \\
Math score & -0.0003 & -0.003 \\
Disciplinary incident & $(0.001)$ & $(0.004)$ \\
& 0.0002 & 0.002 \\
& $(0.0002)$ & $(0.001)$ \\
\hline
\end{tabular}

Notes: Robust standard errors clustered at the school level are given in parentheses. Each column represents the 'effect' of within-cohort refugee concentration in Spring 2010 on the outcomes of students enrolled in the corresponding grade in 2007-08 and 2008-09, estimated using OLS. Regressions using the 2007-08 outcomes include 43,351 test scores, and 72,080 unique student observations. Regressions using the 2008-09 outcomes include 45,454 test scores, and 74,712 unique student observations. ${ }^{*} p<0.10,{ }^{* *} p<0.05,{ }^{* * *} p<0.01$. 
Appendix Table 10

Within-Cohort Refugee Concentration and Existing Student Outcomes, Schools with High

Cross-Cohort Variance in Refugee Concentration, OLS Results, Controls for School Fixed Effects and Student Characteristics

\begin{tabular}{lccc}
\hline & \multicolumn{3}{c}{ More than 5 Percentage Points } \\
\hline Reading score & Spring 2010 & $2010-11$ & $2011-12$ \\
& 0.007 & $0.009^{*}$ & 0.007 \\
Math score & $(0.004)$ & $(0.005)$ & $(0.006)$ \\
& {$[4,021]$} & {$[3,301]$} & {$[2,957]$} \\
Disciplinary incidents & 0.003 & 0.002 & -0.0002 \\
& $(0.005)$ & $(0.009)$ & $(0.008)$ \\
& {$[3,903]$} & {$[2,603]$} & {$[1,989]$} \\
& 0.0002 & 0.0007 & 0.00003 \\
& $(0.002)$ & $(0.002)$ & $(0.002)$ \\
Reading score & {$[4,077]$} & {$[3,819]$} & {$[3,491]$} \\
& & More than 10 Percentage Points & \\
Math score & 0.009 & 0.005 & $(0.010$ \\
& $(0.007)$ & $(0.004)$ & {$[269]$} \\
Disciplinary incidents & {$[762]$} & {$[397]$} & -0.002 \\
& $0.014^{* *}$ & $0.014^{* *}$ & $(0.018)$ \\
& $(0.004)$ & $(0.006)$ & {$[124]$} \\
& {$[685]$} & {$[183]$} & -0.001 \\
& -0.002 & -0.0004 & $(0.002)$ \\
\hline
\end{tabular}

Notes: Robust standard errors clustered at the school level are given in parentheses. Each column represents the effect of within-cohort refugee concentration in Spring 2010 on the outcomes of incumbent students in Spring 2010, 2010-11 and 2011-12, estimated using OLS and schools with a cross-cohort range in refugee concentration of at least 5 or 10 percentage points. All regressions include the student characteristics (other than maternal attributes) listed in Table 4. Number of observations are given in brackets. ${ }^{*} p<0.10,{ }^{* *} p<0.05,{ }^{* * *} p<0.01$. 
Appendix Table 11

Within-Cohort Refugee Concentration and Existing Student Outcomes, Excluding Outlier Schools, OLS Results, Controls for School Fixed Effects and Student Characteristics

\begin{tabular}{lccc}
\hline & Spring 2010 & $2010-11$ & $2011-12$ \\
\hline Reading score & 0.007 & $0.012^{* *}$ & $0.009^{*}$ \\
& $(0.005)$ & $(0.005)$ & $(0.005)$ \\
Math score & {$[37,181]$} & {$[28,416]$} & {$[23,769]$} \\
& 0.002 & 0.004 & 0.005 \\
Disciplinary incidents & $(0.007)$ & $(0.008)$ & $(0.008)$ \\
& {$[35,506]$} & {$[18,447]$} & {$[13,138]$} \\
& -0.003 & -0.002 & -0.002 \\
& $(0.003)$ & $(0.002)$ & $(0.003)$ \\
\hline
\end{tabular}

Notes: Robust standard errors clustered at the school level are given in parentheses. Each column represents the effect of within-cohort refugee concentration in Spring 2010 on the outcomes of incumbent students in Spring 2010, 2010-11 and 2011-12, estimated using OLS, excluding schools with refugee concentration of at least 5 percentage points. All regressions include the student characteristics (other than maternal attributes) listed in Table 4. Number of observations are given in brackets. ${ }^{*} p<0.10,{ }^{* *} p<0.05,{ }^{* * *} p<0.01$. 
Appendix Table 12

Within-Cohort Refugee Concentration and Existing Student Test Scores and Misbehavior, Student Fixed Effects Models

\begin{tabular}{|c|c|c|c|}
\hline & Reading Score & Math Score & $\begin{array}{c}\text { Disciplinary } \\
\text { incident }\end{array}$ \\
\hline Refugee concentration x Spring 2010 & $0.014^{* * *}$ & 0.003 & $0.013^{* * *}$ \\
\hline & $(0.004)$ & $(0.005)$ & $(0.003)$ \\
\hline Refugee concentration x 2010-11 School Year & $\begin{array}{c}0.007^{*} \\
(0.004)\end{array}$ & $\begin{array}{c}0.002 \\
(0.005)\end{array}$ & $0.016^{* * *}$ \\
\hline Refugee concentration x 2011-12 School Year & $\begin{array}{l}0.017^{* * *} \\
(0.004)\end{array}$ & $\begin{array}{c}0.009 \\
(0.006)\end{array}$ & $\begin{array}{l}0.021^{* * *} \\
(0.004)\end{array}$ \\
\hline $\mathrm{N}$ & $1,916,447$ & $1,920,568$ & $1,920,568$ \\
\hline
\end{tabular}

Notes: Robust standard errors clustered at the school level are given in parentheses. Each column represents the difference-in-differences estimates of the effect of within-cohort refugee concentration on test scores and disciplinary incidents of incumbent students in Spring 2010, and 2010-11 and 2011-12 school years, using students who stayed in the sample continuously between 2008-09 and 2011-12 school years. All regressions include student fixed effects. ${ }^{*} p<0.10,{ }^{* *} p<0.05,{ }^{* * *} p<0.01$. 
Appendix Table 13

Within-Cohort Refugee Concentration and Existing Student Test Scores and Misbehavior, Sibling Analysis

\begin{tabular}{|c|c|c|c|}
\hline & \multicolumn{3}{|c|}{ Spring 2010} \\
\hline & (I) & (II) & (III) \\
\hline Family fixed effects & No & Yes & Yes \\
\hline Student characteristics & No & No & Yes \\
\hline \multirow[t]{3}{*}{ Reading score } & $-0.013^{* *}$ & $0.002^{* *}$ & 0.001 \\
\hline & $(0.006)$ & $(0.001)$ & $(0.001)$ \\
\hline & {$[381,341]$} & {$[381,341]$} & {$[315,655]$} \\
\hline \multirow[t]{3}{*}{ Math score } & $-0.023^{* * *}$ & 0.001 & -0.001 \\
\hline & $(0.008)$ & $(0.002)$ & $(0.003)$ \\
\hline & {$[381,208]$} & {$[381,208]$} & {$[315,519]$} \\
\hline \multirow[t]{4}{*}{ Disciplinary incident } & $0.002^{* *}$ & $0.0007^{* *}$ & 0.001 \\
\hline & $(0.001)$ & (0.0003) & $(0.001)$ \\
\hline & {$[463,300]$} & {$[463,300]$} & {$[316,112]$} \\
\hline & \multicolumn{3}{|c|}{ 2010-11 School Year } \\
\hline \multirow{3}{*}{ Reading score } & $-0.052^{* * *}$ & 0.003 & 0.0004 \\
\hline & $(0.011)$ & $(0.003)$ & $(0.002)$ \\
\hline & {$[352,648]$} & {$[352,648]$} & {$[290,029]$} \\
\hline \multirow[t]{3}{*}{ Math score } & $-0.057^{* * *}$ & 0.004 & -0.002 \\
\hline & $(0.007)$ & $(0.006)$ & $(0.006)$ \\
\hline & {$[275,245]$} & {$[275,245]$} & {$[215,236]$} \\
\hline \multirow[t]{4}{*}{ Disciplinary incident } & $0.001^{* *}$ & $0.0004^{*}$ & 0.0002 \\
\hline & $(0.001)$ & $(0.0002)$ & $(0.0003)$ \\
\hline & {$[452,891]$} & {$[452,891]$} & {$[310,491]$} \\
\hline & \multicolumn{3}{|c|}{ 2011-12 School Year } \\
\hline \multirow[t]{3}{*}{ Reading score } & $-0.064^{* * *}$ & 0.005 & 0.006 \\
\hline & $(0.009)$ & $(0.004)$ & $(0.005)$ \\
\hline & {$[308,333]$} & {$[308,333]$} & {$[249,640]$} \\
\hline \multirow[t]{3}{*}{ Math score } & $-0.061^{* * *}$ & 0.003 & -0.007 \\
\hline & $(0.007)$ & $(0.010)$ & $(0.013)$ \\
\hline & {$[215,220]$} & {$[215,220]$} & {$[159,303]$} \\
\hline \multirow[t]{3}{*}{ Disciplinary incident } & $0.004^{* * *}$ & 0.001 & -0.0004 \\
\hline & $(0.001)$ & $(0.001)$ & $(0.001)$ \\
\hline & {$[442,828]$} & {$[442,828]$} & {$[303,570]$} \\
\hline
\end{tabular}

Notes: Robust standard errors clustered at the school level are given in parentheses. In all regressions we restrict the sample to students with at least one sibling in the school system. Numbers in brackets represent the number of observations used in the corresponding specification. Each column represents the effect of within-cohort refugee concentration in Spring 2010 on the test scores and disciplinary incidents of incumbent students in Spring 2010, 2010-11, and 2011-12, estimated using OLS. Columns labeled as (I) and (II) only include students with non-missing lagged outcome variable for the outcome specified. Columns labeled as (III) introduce the student characteristics (other than maternal attributes) listed in Table $4 .{ }^{*} \mathrm{p}<0.10,{ }^{* *} \mathrm{p}<0.05,{ }^{* * *} \mathrm{p}<0.01$. 